\title{
ESTUDO DE EPISÓDIOS DE ZONAS DE CONVERGÊNCIA DO ATLÂNTICO SUL (ZCAS) SOBRE A AMÉRICA DO SUL
}

\author{
Mário Francisco Leal de Quadro \\ Dissertação de Mestrado em Meteorologia, orientada pela Dra. Magda Luzimar de Abreu, aprovada \\ em 25 de novembro de 1993
}

Neste trabalho são definidos parâmetros meteorológicos que possam vir a caracterizar a presença da Zona de Convergência do Atlântico Sul (ZCAS) sobre o Brasil. Os efeitos da ZCAS sobre esta região também são investigados. Durante os versões (Hemisfério Sul) de 1980 a 1989 foram selecionados e analisados 28 epis6dios de ZCAS sobre a América do Sul. A análise visual de imagens de satélites geostacionários mostrou a Convecção Tropical organizada, em termos de faixa com orientação NW/SE, associada à presença de sistemas frontais oriundos do sul do continentes sulamericano. Dados em altitude do ECMWF em conjunto com dados de precipitação fornecidos pelo INMET foram analisados. As análises sugerem que um episódio de ZCAS deva ocorrer associado aos seguintes padrões meteorológicos: convergência de umidade na baixa e média troposfera; faixa de movimento ascendente do ar com orientação NW/SE; um cavado semi-estacionário sobre a costa leste da América do Sul em $500 \mathrm{hPa}$; intenso gradiente de $\theta_{0}$ na média troposfera e também uma faixa de vorticidade relativa anticiclônica em altos níveis $(200 \mathrm{hPa})$. Este trabalho sugere que a ocorrência de chuvas persistentes sobre as regiões afetadas pela ZCAS é uma característica marcante nos episódios estudados. Através da comparação de dois casos extremos de ZCAS sugere-se que, durante um evento de El Niño, a ZCAS apresenta-se inibida ou tende a se formar fora de sua região preferencial de ocorrência (aproximadamente ao norte de $25^{\circ} \mathrm{S}$ sobre a costa leste do continente sulamericano).
CASE STUDY OF THE SOUTH ATLANTIC CONVERGENCE ZONE (SACZ) OVER THE SOUTH AMERICA-In this Thesis is defined a set of meteorological parameters which characterize the presence of the South Atlantic Convergence Zone (SACZ) over the Brazilian Southeast region. The effects of the SACZ over this region is also investigated. Episodes which characterized the presence of the SACZ over South America during the Southern Hemisphere summer from 1980 to 1989 were selected and analysed. The selected episodes presented Tropical Convection organized by frontal systems as observed using geostationary satellite, ECMWF data and precipitation from INMET. The analyses suggest that the following meteorological features are observed at the same time: humidity convergence in the low and middle troposphere; ascendant air motion organized in NW/SE direction; a semistationary trough over the southeastern South America, aproximately along the Brazilian and Uruguaian coasts at $500 \mathrm{hPa}$; strong equivalent potential temperature gradient in middle troposphere and an anticyclonic circulation band at high levels $(200 \mathrm{hPa})$. The work suggests that the persistent precipitation directed NW/SE is a main characteristic of a SACZ episode. Two extreme cases of $S A C Z$ were analysed and the results show that during $E l$ Nifio events the SACZ is either inhibited or it is localized further to the south of its prefered position (north of $25^{\circ} \mathrm{S}$ over the coast of South America).

\section{UM ESTUDO OBSERVACIONAL SOBRE O PADRÃO DE DIPOLO DE ANO- MALIAS DE TEMPERATURA DA SUPERFÍCIE DO MAR NO OCEANO ATLÂNTICO TROPICAL}

\author{
Everaldo Barreiros de Souza \\ Dissertação de Mestrado em Meteorologia, orientada pelo Dr. Paulo Nobre, aprovada \\ em 07 de fevereiro de 1997
}

Neste trabalho investigou-se, sob o ponto de vista observacional, as características dominantes da circulação atmosférica de grande escala, desde a superfície até os altos níveis da troposfera, durante os anos em que se observaram a manifestação dos eventos do Padrão de Dipolo sobre a Bacia do Atlântico Tropical. Os eventos de Dipolo foram selecionados pelos anos que apresentaram o sinal contrario entre os índices normalizados de TSM computados nas Bacias Norte e Sul do Atlântico Tropical (Servain, 1991). Os
AN OBSERVATIONAL STUDY ABOUT THE SEA SURFACE TEMPERATURE ANOMALIES DIPOLE PATTERN OVER THE TROPICAL ATLANTIC OCEAN-This work presents an observational analysis of the large scale atmospheric circulation domain at the surface and high levels of the troposphere, during the periods in wich dipole events were observed over the Tropical Atlantic Ocean. The dipole events were selected looking the SST 
resultados mais importantes das analises dos campos compostos. mensais e sazonais, calculados para um total de 11 casos para cada fase positiva e negativa do Dipolo, foram os seguintes:

As relações entre as variáveis - oceânicas e atmosféricas na superfície do Atlântico concordaram com os estudos anteriores (Hastenrath e Heller, 1977; Nobre, 1993; Nobre e Shukla, 1996) e o gradiente térmico norte-sul e interhemisférico modulou o posicionamento da banda de nebulosidade e precipitação associada à Zona de Convergência Intertropical e, consequentemente, as anomalias de precipitação durante os meses da pró-estação e estação chuvosa do setor norte do Nordeste Brasileiro. As análises observacionais da circulação atmosférica em altitude evidenciaram a manifestação da circulação meridional anômala e termicamente direta simulada por Moura e Shukla (1981). Durante a fase de desenvolvimento dos eventos de Dipolo observados sobre a Bacia do Atlântico Tropical, os fluxos das radiações de onda curta e longa e os fluxos de calor latente. (associado aos processes evaporativos da água oceânica) agem cooperativamente para a gênese e manutenção do padrão inverso de anomalias de TSM relacionado ao modo do Dipolo. standardized indices calculated to the North and South Atlantic Basins (Servain, 1991). The analysis of the monthly and seasonal composites computaded for eleven cases of both positive and negative phases of the Dipole, reveal the following results:

The relationship between atmospheric and oceanic variables over the tropical Atlantic surface, agree with previous works (Hastenrath and Heller, 1977; Nobre, 1993; Nobre and Shukla, 1996) and the interhemispheric SST gradient is crucial in steering the position of the Intertropical Convergence Zone, which is the major precipitation producing system for the rainy season (February through May) of Northeast Brazil. The anomalous meridional circulation, simulated by Moura and Shukla (1981), it was evidenced by the observational analysis of the atmospheric circulation in the troposphere of the Atlantic Ocean. During the development phase of the Dipole events observed over the Tropical Atlantic Basin, the short and long wave fluxes and latent heat fluxes (associated with evaporative processes) act together to the genesis and maintenance of the inverse SST anomalies pattern related with Dipole mode

\title{
SIMULAÇÃO DE GEADAS NO SUL DO BRASIL COM UM MODELO DE ÁREA LIMITADA
}

\author{
Marilene de Lima
}

\begin{abstract}
Dissertação de Mestrado em Meteorologia, orientada pela Dra. Mary Toshie Kayano e pelo Dr. Valdir
\end{abstract} Innocentini, aprovada em 28 de novembro de 1997.

\begin{abstract}
Neste trabalho foi testado o potencial do modelo de área limitada desenvolvido por pesquisadores da Divisão de Previsão Numérica do Japan Meteorological Agency para simular casos de geadas para o Sul do Brasil. Foram feitas simulações usando este modelo com 24 horas e 48 horas de antecedência ao primeiro dia de geada para 14 casos de geadas intensas que ocorreram na década de 80. 0 desempenho do modelo foi avaliado considerando quatro variáveis (temperatura próxima à superfície, pressão ao nível do mar, ventos e geopotencial em $200 \mathrm{hPa}$ ) e comparando os campos simulados com os campos das análises do próprio modelo, bem como os campos correspondentes nas análises do ECMWF. Comparações entre os campos simulados e as analises do próprio modelo do JMA mostram que, em geral, o modelo reproduz bem tanto o padrão como os valores das quatro variáveis, principalmente no que concerne às simulações com 24 horas de antecedência. Para simulações com 48 horas de antecedência, embora os padrões simulados e os das correspondentes análises sejam similares, os valores das variáveis em baixos níveis em alguns casos não foram bem simulados.
\end{abstract}

\begin{abstract}
FROST SIMULATION IN THE SOUTHERN BRAZIL WITH A LIMITED AREA MODEL-In this work, the limited area model developed by researchers of the Numerical Prediction Division of the Japan Meteorological Agency was tested in simulating frosts in the Southern Brazil. Simulations have been done with 24 and 48 hours preceding the first day of frost, for 14 cases of severe frosts occurred at decade of 80. The model performance was evaluated considering four variables (temperature near the surface, sea level pressure, 200-hPa winds and geopotential height) and comparing simulated fields with those from the analysis of the model, as well as with the corresponding analyzed fields of the ECMWF. Comparisons between simulated and analyzed fields show that the model, in general reproduces the variable patterns and their values mainly for simulations with 24 hours of antecedence. For simulations with 48 hours of antecedence although the simulated and analyzed patterns are similar, the values of low level variables, in some cases have not been well reproduced.
\end{abstract}




\section{ESTUDO DA INTERAÇÃO FEIXE DE ELÉTRONS-PLASMA EM UMA MÁ- QUINA DE PLASMA QUIESCENTE}

\section{Fábio do Prado}

Tese de doutorado em Ciência Espacial / Geofísica Espacial, orientada pela Dra. Maria Virginia Alves, aprovada em 16 de dezembro de 1997.

Este trabalho apresenta um estudo da excitação de ondas de Langinuir a partir da injeção de um feixe de elétrons no plasma gerado na miquina de plasma quiescente, PQUI, e descreve a evolução desta interação à medida que o sistema feixe-plasma se desenvolve para um regime de turbulância forte quando a instabilidade modulacional é excitada. Os efeitos dos processes não-lineares são investigados experimentalmente através das mudanças no processo de relaxamento do feixe de elétrons e no comportamento do espectro das ondas de Langmuir.
ELECTRON BEAM-PLASMA INTERACTION STUDY IN A QUIESCENT PLASMA MACHINE-This work is an experimental study of Langmuir waves generation by the interaction between a weak electron beam and a plasma created in a quiescent plasma machine, called PQUI. This work describes the evolution of such beam-plasma system to a strong Langmuir turbulence regime. The non-linear effects of modulational instability are studied by means of the changes in the processes of beam relaxation and in the Langmuir wave spectrum.

\section{ESTIMATIVA REGIONAL DE FLUXOS DE CALOR SENSÍVEL E LATENTE EM ÁREAS DE FLORESTA E PASTAGEM NA AMAZÔNIA}

\section{Julio Tóta da Silva}

Dissertação de Mestrado em Meteorologia, orientada pelo Dr. Gilberto Femando Fisch, aprovada em 13 de março de 1998.

Medidas de superfície e da Camada Limite Planetária (CLP) realizadas nas áreas de floresta $\left(10^{\circ} \mathrm{O} 5^{\prime} \mathrm{S}-10^{0} 19^{\prime} \mathrm{S}\right.$ e $61^{0}$ $\left.35^{\prime} \mathrm{W}-61^{\circ} 57^{\prime} \mathrm{W}\right)$ e de pastagem $\left(10^{\circ} 45^{\prime} \mathrm{S}\right.$ e $\left.62^{\circ} 22^{\prime} \mathrm{W}\right)$ na regido de Ji-Parani, RO, durante o experimento da camada limite de Rondônia (Rondônia Boundary Layer Experiment - RBLE), nas estações secas de julho/1993 (RBLE2) e de agosto/1994 (RBLE3), foram utilizadas para analisar a estrutura e evolução da CLP e também para estimar regionalmente os fluxos turbulentos de calores sensível e latente. Essas estimativas foram comparadas com as medidas dos fluxos de superfície de calores sensível e latente feitas pelo instrumento de correlação de vórtices turbulentos (HYDRA). Perfis de temperatura potencial e de umidade especifica foram obtidos por meio de radiossonda e de balão cativo. As medidas feitas por esses equipamentos foram representativas das características de cada tipo de cobertura de superfície. Durante o ciclo diurno, a estrutura e evolução da CLP sobre a área de pastagem foi bem mais significativa que sobre a área de floresta. As taxas de crescimento entre 11 e 14 HL na área de pastagem chegaram a ser $65 \%$ maiores que na área de floresta durante o RBLE3, com valores de 351,5 m $\mathrm{h}^{-1}$ e $229,2 \mathrm{~m} \mathrm{~h}^{-1}$, respectivamente. Séries temporais e médias diárias da altura da CLP e das temperatura, potencial e umidade especifica foram analisadas para as áreas de floresta e de pastagem durante o RBLE2 e RBLE3. As alturas da CLP foram maiores na área de pastagem, além de que, a camada residual para essas áreas manteve-se durante todo o ciclo diurno. As estimativas regionais dos fluxos de calor sensível e de calor latente foram feitas através da inversão de um modelo simples de camada bem misturada, o qual usa os parâmetros obtidos dos perfis das propriedades da CLP. Dois modelos simples, baseados nas equações de conservação para a CLP, foram usados para estimar estes fluxos. Um
REGIONAL ESTIMATES OF SENSIBLE AND LATENT HEAT FLUXES ON FOREST AND PASTURE AREAS IN THE AMAZONIA-Surface and Planetary Boundary Layer $(P B L)$ measurements were carried out over forest $\left(10^{0}\right.$ $05^{\prime} \mathrm{S}-10^{\circ} 19^{\prime} \mathrm{S}$ e $\left.61^{0} 35^{\prime} \mathrm{W}-61^{\circ} 57^{\prime} \mathrm{W}\right)$ and pasture $\left(10^{\circ}\right.$ 45'S e 620 22' $W$ ) areas at Ji-Parana, RO, during the Rondônia Boundary Layer Experiment - RBLE in the July/ 1993 (RBLE2) and August/1994 (RBLE3) dry seasons. These data sets were used to examine the structure and growth of the PBL, and to estimate regional fluxes of sensible and latent heat. These estimates were compared with surface fluxes of sensible and latent heat measurements made with an eddy correlation intrument (HYDRA). Profiles of the potential temperature and specific humidity were obtained through rawinsonde and tethered balloon data. These measurements were representative of the characteristics of each type of the covered surface. During the daily cycle, the structure and growth of the PBL above the pasture area is more significant than above the forest area. The growth rate betweem I I and 14 local hours at the pasture area reaches values $65 \%$ greater than in the forest area during RBLE3, with values of $351.5 \mathrm{~m} \mathrm{~h}^{-1}$ and $229.2 \mathrm{~m} \mathrm{~h}^{-1}$, respectively. Time series and daily mean of the PBL height and of the potential temperature and the specific humidity were examined in the forest and the pasture areas during both RBLE2 and RBLE3. The PBL heights were greater in pasture area, and the residual mixed layers for this area were maintained during the whole daily cycle. The estimates of sensible and of latent heat fluxes were made through the inversion of a simple slab model, initialized with parameters obtained from profiles of the $P B L$ properties. Two models, based on the conservation equation of the PBL, were used to estimate regional fluxes of sensible and latent heats. One of these models includes the horizon- 
desses modelos incluiu em suas equações um termo para estimar a advecção horizontal. Os resultados mostraram que, para o caso das estimativas dos fluxos de calor sensível, o modelo sem advecção tendeu a superestimar os fluxos medidos pelo HYDRA, tanto na área de floresta quanto em área de pastagem. Neste caso, o Desvio Médio Quadrático (DMQ) e o Viés médio global das estimativas do fluxo de calor sensível,na floresta, foram de $45,1 \mathrm{~W} \mathrm{~m}^{-2} \mathrm{e}-20 \mathrm{~W} \mathrm{~m}^{-2}$ e, para a pastagem, foram de $67,2 \mathrm{~W} \mathrm{~m}^{-2} \mathrm{e}-28,5 \mathrm{~W} \mathrm{~m}^{-2}$. Para o caso dos fluxos de calor latente, o modelo sem adveção superestimou grosseiramente os fluxos medidos. Já o modelo que inclui o termo de advecção simula melhor os valores medidos tanto de calor sensível (floresta: DMQ 39,5 W $\mathrm{m}^{-2}$ e Viés -8,5 $\mathrm{W} \mathrm{m}^{-2}$; pastagem: DMQ 5 5,0 $\mathrm{W} \mathrm{m}^{-2} \mathrm{e}$ Viés, -1 1,62 $\mathrm{W} \mathrm{m}^{-2}$ ) como de calor latente (floresta: DMQ 64,8 $\mathrm{W} \mathrm{m} \mathrm{m}^{-2}$ e Viés 5,9 $\mathrm{W} \mathrm{m}^{-2}$ - pastagem: DMQ 137,7 $\mathrm{W} \mathrm{m}^{-2} \mathrm{e}$ Viés $-29,8 \mathrm{Wm}^{-2}$ ). Estes resultados sugerem que houve uma diferença significativa entre as estimativas em escala regional dos fluxos e aqueles medidos em único ponto. Apesar da simplicidade dos modelos, estes fornecem uma alternativa para estimar fluxos de superfície, conhecidas propriedades da CLP obtidas através de radiossonda e de balão cativo.

\section{ESTUDO DA INFLUÊNCIA DAS ESTRUTURAS COERENTES E DA RUGOSIDADE NA ESTIMATIVA DE FLUXOS TURBULENTOS SOBRE 0 PANTANAL}

\section{Mauricio José Alves Bolzan}

Dissertação de Mestrado em Meteorologia, orientada pelo Dr. Leonardo Deane de Abreu Sá e pelo Dr. Gannabathula Sri Sesha Durga Prasad, aprovada em 12 de março de 1998.

Analisaram-se dados turbulentos de resposta rápida da velocidade do vento e da temperatura, medidos simultaneamente em duas alturas diferentes, em torre micrometeorológica instalada na Reserva de Passo do Lontra (19034,3’S;5701,3’0), município de Miranda, MS, pertencente à Universidade Federal do Mato Grosso do Sul, durante o período de setembro e Outubro de 1996, correspondente à estação seca no Pantanal Matogrossense. O campo experimental é plano, mas as condições superficiais aí são complexas, pois se caracterizam pela existência de arbustos esparsos, de aproximadamente $8 \mathrm{~m}$ de altura, os quais, juntamente com gramínea de aproximadamente $2 \mathrm{~m}$ de altura, compõem a cobertura vegetal da região, típica do Cerrado. Utilizou-se o método das covariâncias para estimar os fluxos turbulentos de momento de calor sensível. Aplicou-se a Transformada em Ondeletas para separar a média da flutuação turbulenta e para detectar e visualizar estruturas coerentes nos campos de velocidade do vento e de temperatura. A ondeleta discreta biortogonal foi utilizada na detecção dos padrões coerentes e a ondeleta continua do chapéu mexicano foi usada para a elaboração de diagramas em tempoescala das flutuações dos sinais. Novos critérios de Classificação das condições de estabilidade atmosférica foram aplicados no sentido de agrupar os dados disponíveis e propiciar estudo da variação da fração do fluxo turbulento as-
A STUDY OF THE INFLUENCE OF THE COHERENT STRUCTURES AND OF THE ROUGHNESS IN THE ESTIMATE OF TURBULENT FLUXES ON THE PANTANAL-The fast response turbulent data consisting of the wind velocity and the temperature, measured simultaneously at two different heights on a micrometerological tower installed in the Reserve Passo do Lontra, (19034.3'S;5701.3'0) covered district of Miranda, MS, is analyzed. The data used is for the period September to October 1996, which corresponds to the dry season in the Pantanal Matogrossense. The experimental site region is flat plane, but with quite complex surface condition. The surface of the site is covered by grasses with height of $2 \mathrm{~m}$ and composed of the vegetation typical of the region, along with sparsely spaced trees which grow to about $8 \mathrm{~m}$. The momentum and sensible heat fluxes are estimated using the method of covariance. The Wavelet Transform is applied to separate the turbulent fluctuations, and to separate and visualize the coherent structures, in the wind and temperature fields. The biorthogonal wavelet is used for the detection of the coherent structures and the continuous wavelet (Mexican hat) is used to examine the turbulent fluctuations in time scale. New criteria for the classification of the stability conditions of the atmosphere are used to group the data, and to study the fraction of turbulent flux associated with 
sociado a estruturas coerentes em função das condições de estabilidade atmosférica e também da altura. Técnicas de separação em quadrantes, das contribuições e das flutuações turbulentas para os fluxos, foram utilizados para melhor compreensão dos processos físicos de intrusão e de ejeção turbulentas. Testes estatísticos serviram para verificar se fluxos turbulentos poderiam ser considerados como constantes com a altura. $\mathrm{O}$ estudo se estendeu a diversas bandas de freqüências que contribuem para o coespectro turbulento. Os resultados mostram um comportamento marcadamente diferente para as estruturas coerentes térmicas e mecânicas, salvo em condições muito próximas da neutralidade. Nestas, predominam padrões de flutuação associados a escalas temporais da ordem de $100 \mathrm{~s}$, as quais provavelmente são manifestações de estruturas do tipo "rolo". Sob condições moderadamente instáveis ou sob convecção livre, as estruturas coerentes apresentam menor localização em escala, e parece ocorrer um regime misto em que se verificam contribuições tanto de escalas temporais da ordem de $50 \mathrm{~s}$ (típicas daquelas verificadas acima de superfícies "lisas"), quanto as da ordem de $100 \mathrm{~s}$, típica de superfícies extremamente rugosas, e possivelmente associadas com a chamada instabilidade do ponto de inflexão. Sob certas condições de estabilidade atmosférica, constatou-se que os fluxos medidos em duas alturas diferentes (5 m de separação) são estatisticamente diferentes. the coherent structures as a function of the height and stability conditions. Techniques for the separation into quadrants of the turbulent fluctuations are used to better understand the physical processes involved in the intrusion and ejection. Statistical tests are used to verify if the turbulent fluxes are constant with height. The study used various frequency bands that contribute to the turbulent cospectrum. Results show that there is marked difference in the behavior of the thermal and momentum coherent structures, except in conditions of near neutral stability. In these cases, the predominant patterns of fluctuations on scales of about $100 \mathrm{~s}$ appear to be related to the roll type structures. Under moderately unstable conditions and in $f$ ree convection, the patterns of the coherent structures are not well localized in scale, and appear to belong to a mixed regime, varying from temporal scales of $50 \mathrm{~s}$ (typical of "smooth" surfaces) to scales of the order of $100 \mathrm{~s}$ (typical of very rough surfaces), and are probably associated with the so called "point of instability". Under certain conditions of atmospheric stability, the fluxes measured at the two different heights (5 $\mathrm{m}$ separation) are statistically different.

\title{
INFERÊNCIA DE PERFIS VERTICAIS DE TEMPERATURA UTILIZANDO UMA TÉCNICA ITERATIVA IMPLÍCITA DE INVERSÃO João Carlos Carvalho
}

\author{
Dissertação de Mestrado em Meteorologia, orientada pelo Dr. Nelson Jesus Ferreira e pelo Dr. \\ Fernando Manuel Ramos, aprovada em 13 de março de 1998.
}

Neste trabalho foi utilizado um método iterativo implícito de inversão (MIII) para obtenção de perfis verticais de temperatura, baseado no processo de inversão matemática da Equação Integral da Transferência Radiativa (EITR). Basicamente este método procede a minimização de um funcional composto por uma norma quadrática mais um termo de regularização, utilizando em sua resolução uma rotina numérica de minimização. Além das funções clássicas de regularização de Tikhonov, utilizou-se regularização baseada no princípio da máxima entropia. Numa primeira etapa, apresenta-se uma série de simulações baseadas em dados gerados sinteticamente a partir da EITR, onde foi possível proceder vários testes, tais como convergência, comparação com outras técnicas e análise de erro. Em seguida, aplica-se o MIII a uma situação real com dados de radiâncias fornecidas pelos sensores do HIRS/2 (Hight Resolution Infrared Radiation Sounder). Finalmente, apresenta-se uma comparação com perfis obtidos por radiossondagem. De um modo geral, os resultados obtidos nas simulações realizadas para avaliar a técnica atestam o bom desempenho do MIII, sobretudo nos níveis de pressão que vão da superfície até a inversão da tropopausa, que é a região de maior interesse meteorológico.

\begin{abstract}
RETRIEVAL OF VERTICAL TEMPERATURE PROFILES IN THE ATMOSPHERE USING AN ITERATIVE IMPLICIT INVERSION TECHNIOUE-In this work, we present an iterative implicit inversion method (MIII) to retrieve vertical temperature profiles based on the mathematical inversion of the radiative transfer equation (RTE). The inverse problem is formulated as a nonlinear constrained optimization problem. A regularization term is added to the objective function with the help of a Lagrange multiplier. The regularization function considered is the Tikhonov regularization, and regularization based on the maximum entropy principle. As a first step, it is presented a set of simulations using synthetic data obtained directly from the RTE, then, the method is applied in a real situation with radiance data given by the HIRS/2 (Hight Resolution Infrared Radiation Sounder) sensors. Finally, a comparison with profiles obtained by radiosonde is presented. In general, the proposed algorithm converges to excellent temperature profiles mainly in the tropopause inversion region.
\end{abstract}




\title{
ANÁLISE E MODELAGEM DE CURVAS DE CORRENTE DE RELÂMPAGOS NEGATIVOS DESCENDENTES ENTRE 1985 E 1994 NA ESTAÇÃO DE PES- QUISA DO MORRO DO CACHIMBO-MG
}

\author{
Moacir Lacerda
}

\author{
Tese de Doutorado em Geofísica Espacial, orientada pelo Dr. Osmar Pinto Júnior e pela \\ Dra. Iara Regina Cardoso de Almeida Pinto, aprovada em 24 de junho de 1998.
}

\begin{abstract}
Apresenta-se uma análise de 22 relâmpagos negativos descendentes registrados no Brasil entre 1985 e 1994, na Estação de Pesquisa do Morro do Cachimbo (43 $58^{\prime}$ 26" W, $20^{\circ}$ 00' 39" S), da Companhia Energética de Minas Gerais (CEMIG). Faz-se um resumo do histórico da pesquisa de correntes de descargas capturadas em torre e descreve-se a técnica de medida. Comparando-se os primeiros choques de retorno com aqueles de outra estação de pesquisa na $\mathrm{Su}-$ íça, observou-se que as curvas de corrente são muito similares nos dois países, embora a intensidade média dos picos da corrente no Brasil (40 kA) seja maior que aquelas na Suíça (30 kA) e o instante em que ocorre o pico no Brasil (22 $\mu \mathrm{s})$, seja maior que na Suíça (13 $\mu \mathrm{s})$. Diferenças foram percebidas também nos choques subsequentes. Para explicar tais diferenças foi desenvolvida uma extensão ao modelo de Borovski onde a condutividade do sistema canal-torre atmosfera-solo pode ser calculada diretamente da curva de corrente. As condutividades foram calculadas pelo novo modelo ajustando-se as curvas médias, obtendo-se $1.21 \times 10^{-6}$ $(\Omega \mathrm{m})^{-1} 2.74 \times 10^{-6}(\Omega \mathrm{m})^{-1}$ no Brasil e na Suíça. As diferenças entre os valores dos picos de corrente e condutividade encontrados foram explicadas com base no cálculo dos campos elétricos, usando-se a lei de Ohm. HA uma correlação linear $(\sim 94 \%)$ entre o instante em que a corrente atinge o pico e aquele em que a derivada da corrente é máxima. Os terceiros choques apresentaram correntes mais intensas que os segundos e uma explicação para esse fato foi apresentada. Componentes $\mathrm{M}$ foram registradas em torno de $200 \mu \mathrm{s}$ com valores de pico ( 2 kA) sendo atingidos em tempos menores que aqueles registrados em componentes $\mathrm{M}$ registradas após $1 \mathrm{~ms}$ em outras estações de pesquisa.
\end{abstract}

\begin{abstract}
ANALYSIS AND MODELLING OF NEGATIVE DOWNWARD LIGHTNING CURRENT CURVES BETWEEN 1985 AND 1994 AT MORRO DO CACHIMBO RESEARCH STATION (MG)-In this thesis is presented an analysis of 22 negative descendent lightning collected in Brazil from 1985 to 1994 in the "Morro do Cachimbo" research station ( $\left.43^{\circ} 58^{\prime} 26^{\prime \prime} \mathrm{W}, 20^{\circ} 00^{\prime} 39^{\prime \prime} S\right)$ of the Companhia Energética de Minas Gerais (CEMIG). The historic evolution of direct discharge measurements and the techniques involved are summarised. From the comparison of first return strokes with those of another station in Switzerland, it was noted that electric current wave forms are similar in both countries, although the mean peak current in Brazil (40kA) is greater than that in Switzerland (30 kA) and the average instant at which the peak occurs is greater in Brazil $(22 \mu \mathrm{s})$ than in Switzerland $(13 \mu \mathrm{s})$. Differences in subsequent strokes were observed too. To explain such differences it was developed an extension of the Borovski model, from which the conductivity of channel-toweratmosphere-ground system was calculated straightly from mean current curves. The values obtained were $1.21 \times 10^{-6}$ $(\Omega \mathrm{m})^{-l}$ (Brazil) and $2.74 \times 10^{-6}(\Omega \mathrm{m})^{-l}$ (Switzerland). The differences in the peak current and conductivity values were explained based on Ohm's Law. It was found that the time to peak current is correlated to the time to peak of derivative current with a linear correlation coeficient of about $94 \%$.The mean third return stroke current was found to be stronger than the second and an explanation for that was suggested. $M$ components recorded at about $200 \mu$ s (peak current values $\sim 2 k A$ ) had time to peak lower than those obtained after 1 $m$ in other research stations.
\end{abstract}

\section{ESTUDOS DE DERIVAS IONOSFÉRICAS POR MEIO DE IONOSSONDAS DIGITAIS}

\section{Fernando Celso Perin Bertoni}

Dissertação de Mestrado em Geofísica Espacial, orientada pela Dra. Inez Staciarini Batista e pelo Dr. Mangalathayil Ali Abdu, aprovada em 25 de setembro de 1998.

Utilizaram-se as ionossondas digitais DGS256 (Digissonda), em São Luís (MA) $\left(2,3^{\circ} \mathrm{S} ; 42^{\circ} 0\right)$ e Canadian Advanced Digital Ionosonde (CADI), em Fortaleza (CE) $\left(4^{\circ} \mathrm{S} ; 38^{\circ} 0\right)$, ambos os instrumentos situados em localidades da região equatorial brasileira, para estudar as derivas do plasma ionosférico sobre essas regiões. Procurou-se discutir a validação do seu uso, por meio de comparação dos resultados apresentados por esses instrumentos, com os encontrados na literatura, visando uma opção a mais em termos de
IONOSPHERIC DRIFT STUDIES BY DIGITAL IONOSONDES-The ionospheric plasma drifts over the Brazilian region were studied using data from the digital ionosondes DGS256, at São Luís (MA) $\left(2,3^{0} \mathrm{~S} ; 42^{\circ} \mathrm{W}\right)$ and CADI (Canadian Advanced Digital lonosonde), at Fortaleza $(C E)\left(4^{0} \mathrm{~S} ; 38^{0} \mathrm{~W}\right)$, both instruments located at equatorial region. In order to validate the use of those instruments to measure ionospheric plasma drifts, we made intercomparison of the results of both instruments, and 
instrumentação, para posterior desenvolvimento de pesquisas a respeito das derivas da ionosfera sobre essas regiões brasileiras. Observou-se que a componente vertical da velocidade de deriva ionosférica apresentada pela DGS256, não concordou inteiramente com aquela exibida pelo radar de espalhamento incoerente de Jicamarca, devido às diferenças instrumentais. Enquanto que o radar mede a deriva eletromagnética, a DGS256 mede a deriva aparente. Entretanto, a componente vertical de velocidade de deriva sobre São Luís exibe um aumento pró-inversão, após o pôr-do-Sol bem conhecido em latitudes equatoriais. A componente zonal da DGS256 apresentou boa concordância com a do radar de Jicamarca. A comparação dos resultados de deriva vertical obtidos tanto com a DGS256 como com a CADI, demonstraram concordância entre si, somente em algumas faixas de horário, tal concordância levou a acreditar que as medidas efetuadas por esses dois instrumentos poderiam estar certas. Foram cogitadas hipóteses com relação a condições especificas da configuração dos campos elétricos da região $\mathrm{F}$ ionosférica, para explicar tanto a concordância como a discordância entre as curvas de componentes vertical e zonal de deriva ionosférica obtidas com ambos os instrumentos. comparison with previous results available in the literature, as well, seeking for one more instrumentation option, for future ionospheric drift research development over those Brazilian regions. It was observed that ionospheric vertical drift velocity measured by DGS256 did not totally agree with that exhibited by Jicamarca's incoherent scatter radar due to instrumental differences. The drift measured by the radar is the electromagnetic drift while the DGS256 measures the apparent drift. However the pre-reversal enhancement that is a well known characteristic of the vertical drift velocity at equatorial latitudes after sunset, is also observed on DGS256 drifts over São Luís. The zonal drift provided by DGS256 agrees well with that obtained by the Jicamarca's radar. The comparison between DGS256 and CADI vertical drift velocities shows good agreement during some time periods and under certain magnetic activity conditions. The results are discussed in terms of the variability of the low latitude electric fields and the differences between quiet and disturbed conditions.

\title{
ESTUDO DE MICROPULSAÇÕES GEOMAGNÉTICAS PC3-5 EM LATITU- DES MUITO BAIXAS, NO BRASIL
}

\section{Ademilson Zanandrea}

\author{
Tese de Doutorado em Ciência Espacial/Geofisica Espacial, orientada pelo Dr. José Marques da Costa \\ e pelo Dr. Severino Luiz Guimarães Dutra, aprovada em 11 de dezembro de 1998.
}

Neste estudo, procurou-se compreender os mecanismos de geração e modos de propagação de micropulsações Pc3-5, em latitudes muito baixas e equatoriais. Usou-se dados simultâneos observados corn uma cadeia de 10 estações geomagnéticas, no território brasileiro, dispondo de magnetômetros "fluxgate" de alta sensibilidade. Utilizouse o método de estimação espectral por múltiplas janelas, baseado na Transformada Rápida de Fourier (FFT), para obter os espectros de potência, parâmetros de polarização e fase das micropulsações. Observou-se um aumento na ocorrência das pulsações Pc3-5 altamente polarizadas, atingindo o máximo próximo ao meio dia local (14:00 e 15:00 UT) nas estações mais próximas ao equador magnético. Os espectros dinâmicos mostraram a ocorrência de 81 eventos simultâneos de pulsações Pc3-4 com alto grau de polarização, principalmente durante o dia. Os eventos diurnos mostraram um aumento de 3,2 vezes na densidade de potência polarizada para as pulsações observadas nas estações próximas do equador magnético em comparação com as mais distantes. As fases das pulsações mostraram atrasos entre $48^{\circ} \mathrm{e}$ $62^{\circ}$ nas estações equatoriais em relação as mais distantes. Estes efeitos estão relacionados ao aumento da condutividade ionosférica e da intensidade de eletrojato equatorial. As curvas de densidade de potência polarizada para as 10 estações mostraram um comportamento idêntico, com picos
PC3-5 STUDY OF GEOMAGNETIC MICROPULSATIONS AT VERY LOW LATITUDE, IN BRAZIL-This study is aimed at the understanding of source mechanisms and propagation modes of Pc3-5 micropulsations at very low and equatorial latitudes. It used simultaneous data measured with a chain of 10 geomagnetic stations in Brazil using high sensitive fluxgate magnetometers. Multiple tapered spectral estimation method based on Fast Fourier Transforms (FFT) was used to obtain micropulsation power spectra, polarization parameters and phases. It was observed an increase in the occurrence of highly polarized Pc3-5 pulsations, reaching maxima close to local noon (14:00 and 15:00 UT) in the stations nearest to the magnetic equator. The dynamic spectra showed the occurrence of 81 simultaneous events of Pc3-4 pulsations with high degree of polarization, mainly during daytime. The diurnal events showed increases in the polarized power density of 3,2 times for pulsations observed at stations close to the magnetic equator in comparison to the more distant ones. The phase of the pulsations observed at station close to the magnetic equator showed a delay of $48^{\circ}$ and $62^{\circ}$ in to relation to the most distant one. This effect is clearly related to the increase of ionospheric conductivity and equatorial electrojet intensity. The polarized power density curves for all the 10 stations showed a similar behaviour, the maximum peaks 
máximos ocorrendo na mesma freqüência. Isto esta possivelmente relacionado ao modo de oscilação global da cavidade plasmasférica. A elipticidade mostrou-se quase-linear, com eixo maior na direção norte-sul, devido ao fato de que as oscilações poloidais das linhas de campo magnéticas são quase desacopladas. A amplitude da componentes norte-sul mostrou-se maior que a oeste-leste. Estes resultados são uma evidência de que o mecanismo da ressonância das linhas de campo não explica as micropulsações Pc3-4 observadas em latitudes muito baixas e equatoriais. 0 aumento na ocorrência de eventos Pc3-4 durante o dia, com máximo próximo ao meio-dia local e presença predominante do modo poloidal (compressional), está, provavelmente associado com a propagação da onda compressional, proveniente da instabilidade íon-ciclotrônica na região da frente de choque, que se propaga na magnetosfera em baixas latitudes. A propagação desta onda pode excitar o modo compressional aprisionado ou o modo global compressional. O fenômeno resultante das oscilações forçadas das linhas de campo na plasmasfera é o mais provável mecanismo fonte das pulsações Pc3-4 em latitudes muito baixas e equatoriais. occurring at same frequency. This may indicate a possible link to the plasmaspheric cavity global oscillation mode. The ellipticity was quase-linear, with the larger axis in the north-south direction, due to the fact that the poloidal mode is almost uncoupled from the oscillation of magnetic field lines. The amplitude of north-south component is much larger than the west-east one. These results could be an evidence that field line resonance mechanism does not explain Pc3-5 micropulsations observed at very low and equatorial latitudes. The increase in the occurrence of Pc34 diurnal events is probably associated with incoming compressional waves resulted from bow shock ion cyclotron instabilities that propagate in the magnetosphere at low latitudes. The propagation of the compressional waves may excite the trapped compressional mode or the compressional global mode. The resulting phenomenon, field lines forced oscillations in the plasmasphere, may be a possible source mechanism for Pc3-4 pulsations at very low latitudes.

\title{
REGISTROS DA ATIVIDADE SOLAR E DE OUTROS FENÔMENOS GEOFÍSICOS EM ANÉIS DE CRESCIMENTO DE ÁRVORES Nivaor Rodolfo Rigozo
}

\author{
Tese de Doutorado em Geofísica Espacial, orientada pelo Dr. Daniel Jean Roger Nordemann, aprovada \\ em 17 de dezembro de 1998.
}

Os estudos dos anéis de crescimento de árvores são, em sua maioria, realizados para verificar ou determinar os fatores climáticos, que estão atuando num local ou região, provocando variações nas espessuras de anéis de crescimento. Poucos estudos são feitos para se verificar e/ou determinar os fenômenos geofisicos, que possam causar variações nas espessuras de anéis de crescimento de Arvores. Apresentase um novo método interativo de análise de imagens na determinação das espessuras dos anéis de crescimento de árvores, para a procura de periodicidades devidas à atividade solar e/ou outros fenômenos geofísicos que estejam influenciando o crescimento dos anéis. O método consiste na utilização de um computador, um digitalizador de mesa de alta resolução e na utilização de um programa desenvolvimento no ambiente "Interactive Data Language" (IDL 5.0) para o estudo das imagens digitalizadas dos anéis de crescimento. A principal vantagem deste método é a analise interativa de imagens dos anéis de crescimento de árvores sem a necessidade de aparelhos complexas de alto custo. Foram coletadas no total 39 amostras, sendo que 12 são de Concórdia - SC, 09 de Canela - RS, 14 de São Francisco de Paula - RS, uma de Nova Petrópolis - RS, 02 de São Martinho da Serra - RS e uma do Chile. Nas séries temporais da espessura dos anéis de crescimento são aplicadas funções de ajustes, a fim de se obter a melhor curva que representa as tendências de longos

\begin{abstract}
RECORD OF THE SOLAR ACTIVITY AND OF OTHER GEOPHYSICAL PHENOMENA IN TREE RING-Tree ring studies are usually used to determine or verify climatic factors which prevail in a given place or region and may cause tree ring width variations. Few studies are dedicated to the geophysical phenomena which may underlie these tree ring width variations. In order to look for periodicities which may be associated to the solar activity and/or to other geophysical phenomena which may influence tree ring growth, a new interactive image analysis method to measure tree ring width was developed and is presented here. This method makes use of a computer and a high resolution flatbed scanner-a program was also developed in Interactive Data Language (IDL 5.0) to study ring digitized images and transform them into time series. The main advantage of this method is the tree ring image interactive analysis without needing complex and high cost instrumentation. Thirty-nine samples were collected: 12 from Concórdia - S. C., 9 from Canela - R. S., 14 from São Francisco de Paula - R. S., one from Nova Petrópolis - R. S., 2 from São Martinho da Serra - R. S. and one from Chile. Fit functions are applied to ring width time series to obtain the best long time range trend (growth rate of every tree) curves and are eliminated through a standardization process that gives the tree ring index time series from which is performed spectral analysis by maximum
\end{abstract}


períodos associadas ao ritmo de crescimento de cada série, na qual é efetuado o procedimento da padronização, através do qual é obtido o índice da espessura dos anéis de crescimento das árvores. Nas análises espectrais foram utilizados os métodos da máxima entropia e da regressão iterativa. Os resultados obtidos pelas análises espectrais mostram periodicidades próximas aos ciclos solares de 11 anos, de Hale, e do segundo harmônico do ciclo de 11 anos em 5,5 anos para todos os locais de coleta. Também se encontrou periodicidades pertencentes aos ciclos solares de 52 anos e Gleissberg, para as amostras de Concórdia - SC e na Cordilheira da Costa de Osomo - Chile. Também se observou eventos do El Niño para períodos em torno de 4 e 7 anos. entropy method and iterative regression. The results obtained show periodicities close to I I yr, 22 yr Hale solar cycles and $5.5 \mathrm{yr}$ for all sampling locations, $52 \mathrm{yr}$ and Gleissberg cycles for Concórdia - S. C. and Chile samples. El Niño events were also observed with periods around 4 and $7 y r$.

\section{SONDAGENS MAGNETOTELÚRICAS TRANSVERSAIS À BACIA DE TAUBATÉ}

\section{Paula Marcia Aranha de Brito}

\section{Dissertação de Mestrado em Ciência Espacial/Geofísica Espacial, orientada pelo Dr. Antônio Lopes Padilha e pelo Dr. Ícaro Vitorello, aprovada em 18 de dezembro de 1998.}

Na região da Bacia Taubaté foram realizadas treze sondagens magnetotelúricas compreendidas num perfil que cortou transversalmente a bacia em sua parte mais espessa, denominada sub-bacia de Tremembé, e prolongou-se pelas limítrofes Serra do Mar a sudeste e Serra da Mantiqueira a noroeste. Os dados foram interpretados através de um modelo de inversão bidimensional e os resultados testados por uma modelagem direta. Uma camada condutora a $10 \mathrm{~km}$ de profundidade foi observada claramente sob as regiões cristalinas, mas não foi detectada sob as rochas sedimentares. Tal fato pode estar associado a efeitos de encobrimento resultantes da alta condutância dos sedimentos da bacia. A presença dessa camada condutora na crosta médio-inferior parece ser uma característica global, sendo detectada sob as mais diferentes estruturas geológicas. Aqui, porém, apresentou uma condutância anomalamente baixa para uma região retrabalhada no Neo-Proterozóico. Este aspecto deve ser considerado na formulação de qualquer modelo de evolução tectônica da área.

\begin{abstract}
MAGNETOTELLURIC SOUNDINGS ACROSS THE TAUBATÉ BASIN-Thirteen magnetotelluric soundings were carried out in the Taubaté basin region. They were positioned along a profile cutting across the thickest part of the basin, named Tremembé sub-basin, and extending over the Serra do Mar and Serra da Mantiqueira, respectively to the southeast and northwest. The data were interpreted through a 2-D inversion scheme and the results were tested through a forward modelling. A $10 \mathrm{~km}$ deep conductive layer was observed quite clearly under the crystalline regions but was undetected under the sedimentary rocks. The latter can be probably associated with screening effects due to the high conductance of the surface sediments. Studies at different tectonic regions in the world have reported the same conductive layer at around the same depth but in the present study the layer has an anomalously low conductance considering that it is a region which was reworked during the Neo-Proterozoic. These findings are strong constraints to any tectonic model suggested to explain regional features.
\end{abstract}

\section{ESTIMATIVA DE EMISSIVIDADE DA SUPERFÍCIE CONTINENTAL A PAR- TIR DE DADOS DE SATÉLITE}

\section{Rodrigo Augusto Ferreira de Souza}

\section{Dissertação de Mestrado em Meteorologia, orientado pelo Dr. Eduardo Jorge de Brito Bastos e pela}

Dra. Regina Célia dos Santos Alvalá aprovada em 04 de março de 1999

A emissividade da superfície continental foi estimada, a partir de dados de satélite no microondas, para todo o território brasileiro. Utilizou-se uma solução de Equação de Transferência Radiativa (ETR), dados de temperatura de brilho obtidos a partir do Special Sensor Microwave/Imager (SSM/I) e dados de temperatura da superfície obtidos pelo sistema de TIROS Operational Vertical Sounder (TOVS). Estimou-
MICROWAVE LAND SURFACE EMISSIVITIES ESTIMATED FROM SSM/I OBSERVATIONS -Microwave emissivities of land surface were estimated from the Special Sensor Microwave/Imager (SSM/I) observations using the 19 and $85 \mathrm{GHz}$ channels, and surface skin temperature data derived from the Tiros Vertical Sounder (TOVS). The atmospheric contribution was calculated from simulations of the 
se a contribuição atmosférica a partir de simulações do modelo Atmospheric Trasmission at Millimetric and submillimetric wavelengths (ATM). Calculou-se a emissividade da superfície continental para os canais do SSM/I em 19 e 85 GHz, para julho e dezembro de 1997. Para verificar o padrão de rugosidade da superfície fez-se a diferença entre os campos de emissividade de polarização vertical e horizontal. Os resultados mostraram que os padrões regionais e as mudanças sazonais nas estimativas de emissividade da superfície continental são consistentes com a topografia de grande escala e com a distribuição espacial da vegetação. Assim, estimar a emissividade da superfície continental no microondas oferece a possibilidade de recuperar parâmetros atmosféricos (nuvens) e monitorar a superfície terrestre (vegetação, inundação, etc).
Atmospheric Transmission at Millimetric and submillimetric wavelengths (ATM) model. The microwave emissivities over Brazil were estimated for July and December, 1997, using the Radiative Transfer Equation (RTE). The emissivity polarization difference was performed to verify the land surface roughness patterns. The results show that the regional patterns and the vegetation seasonal changes retrieved from the land surface emissivities are compatible with the large scale topography and vegetation distributions. Thus, the estimation of the microwave emissivities of land surface may be used to retrieve some atmospheric parameters (clouds) and monitor the land surface (vegetation, floods, etc).

\title{
USO DA TÉCNICA DE RELAÇÃO DE NEWTON PARA ASSIMILAÇÃO DE DADOS DE SATÉLITE EM UM MODELO DE ÁREA LIMITADA
}

\section{Luis Gustavo Gonçalves de Gonçalves}

\author{
Dissertação de Mestrado em Meteorologia, orientada pelo Dr. Valdir Innocentini aprovada em 08 de \\ março de 1999
}

Este trabalho utiliza a técnica de Relaxação de Newton para permitir uma assimilação contínua no tempo de dados provenientes de sondagens atmosférica inferidas por satélite através do sistema TOVS (Tiros Operational Vertical Sounder). O conjunto de dados a ser assimilado possui uma grande densidade espacial, o que produz matrizes da ordem de até $10^{4}$ elementos. Elaborou-se uma estratégia para a manipulação das matrizes de dados, evitando problemas de ordem computacional, relacionados ao uso de memória e velocidade de processamento. Testes foram feitos com as funções que regularizam a entrada dos dados (funções peso) para a calibração do sistema de assimilação, evitando o aparecimento de ondas espúrias geradas por uma super estimação das observações. Após a implementação técnica, os impactos são verificados em um estudo caso envolvendo situação de ciclogênese no sul do Brasil na qual foram assimiladas dados de temperatura inferidos por satélites. O modelo numérico empregado é de área limitada, utilizado operacionalmente na Divisão das Ciências Meteorológicas do Instituto Nacional de Pesquisas Espaciais (INPE). Os resultados mostram a assimilação de apenas uma variável (temperatura) já é suficiente para influenciar os resultados das previsões. A técnica de relaxação de Newton mostrouse, portanto, eficaz na inserção de dados no MAL, causando problemas numéricos ou alterando de forma irreal os resultados da integração. Os custos de ordem computacional representaram um aumento de até $5 \%$ do tempo em relação à integração sem assimilação, o que viabiliza a implementação operacional da técnica.

\begin{abstract}
USE OF NEWTONIAN RELAXATION TECHNIQUE FOR SATELLITE DATA ASSIMILATION IN A LIMITED AREA MODEL-This work uses the Newtonian Relaxation technique to allow a continuos data assimilation in the time of coming data of atmospheric sounding inferred by satellite through the system TOVS (TIROS Vertical Operational Sounder). The group of data to be assimilated has a great space density, what produces matrixes of the order of up to $10^{4}$ elements. A strategy was elaborated for the manipulation of the matrixes, avoiding computacional order problems, related to the use of memory and processing speed. Tests were made with the functions that regularize data entrance (weight functions) for calibration of the data assimilation system, avoiding spurious waves generated by an overestimate of the observations. After the technique implementation, the impacts are verified in a case study involving a ciclogenesis in southern Brazil in which temperature data inferred by satellite were assimilated. The numerical model used is a limited area model (LAM), used operationally in the Divisão de Ciências Meteorológicas of the Instituto Nacional de Pesquisas Espaciais (INPE). The results show that the assimilation of just a variable (temperature) it is already enough to influence the forecast results. The technique of Newtonian Relaxation was show, therefone, effective in the insert of data in the LAM, not causing numeric problems or altering in an unreal way the results of the integration. The costs of computacional order represented an increase of up to $5 \%$ of time in relation to the integration without assimilation, what makes possible the operational implementation of technique.
\end{abstract}




\title{
VARIABILIDADE DA PRECIPITAÇÃO NA REGIÃO SUL DO NORDESTE E SUA ASSOCIAÇÃO COM PADRÕES ATMOSFÉRICOS
}

\author{
Rosane Rodrigues Chaves
}

\author{
Dissertação de Mestrado em Meteorologia, orientada pela Dra. Iracema Fonseca de Albuquerque \\ Cavalcanti, aprovado em 09 de março de 1999
}

As características da circulação atmosféricas associadas à variabilidade da precipitação durante o período chuvoso principal (NDJ) do sul do Nordeste são determinadas através de ACP, análise de "Cluster" e análise de eventos extremos de precipitação. Utilizou-se dados diários de precipitação, dados de reanálise do NCEP, dados de ROL e dados de TSM. Os sistemas meteorológicos de verão que atuam sobre a América do Sul, bem como fenômenos associados à variabilidade destes, como o ENSO, oscilação 30-60 dias e padrão de onda do Pacífico até a América do Sul são identificados. Nestas análises as anomalias positivas (negativas) de precipitação sobre o sul do Nordestes estão relacionadas à fase positiva (negativa) do ENSO. Na escala intrasazonal verifica-se que a variabilidade da ZCAS, da ZCPS e do cavado do Nordeste estão correlacionadas. Ressalta-se que o padrão chuvoso está relacionado com o deslocamento da ZCAS para norte e da ZCPS para leste e também posicionalmente do cavado Nordeste sobre o Oceano. O padrão seco associa-se com o posicionamento da ZCAS em latitudes mais o sul e o cavado do Nordeste sobre ou próximo ao continente. Verifica-se a influência das condições atmosféricas da Amazônia e do HN na precipitação do sul do Nordeste. O padrão chuvoso está associado à imensa convecção sobre o leste da Amazônia e deslocamento da AB para leste, escoamento em baixos níveis da Amazônia para o Sul do Nordeste e intensificação dos alísios de nordeste sobre a costa setentrional da América do Sul. No padrão seco verifica-se a AB oeste da sua posição climatológica, escoamento em baixos níveis da Amazônia para latitude ao sul e enfraquecimento dos alísios de nordeste sobre a costa norte do América Sul. Sobre o Atlântico Sul o padrão chuvoso associa-se com o deslocamento da Alta Subtropical para leste e enfraquecimento dos alísios de sudeste na costa do Nordeste e o padrão seco com o fortalecimento e/ ou deslocamento da Alta Subtropical para oeste e intensificação dos alísios de sudeste. Em altos níveis, no padrão seco, observa-se que o escoamento é mais zonal e menos intenso sobre a América do Sul e no padrão chuvoso o escoamento é mais intenso sobre a latitudes subtropicais da América do Sul e apresenta uma bifurcação sobre o Pacífico Sudeste.
VARIABILITY OF PRECIPITATION IN THE SOUTHERN REGION OF NORTH-EAST AND ITS ASSOCIATION WITH ATMOSPHERIC STANDARDS-The atmospheric features of circulation associated with the variability of the precipitation during the main rainy period (NDJ) of the south region of Northeast are determined through the ACP, Cluster Analysis and analysis of extreme precipitation events. Daily precipitation data NCEP reanalysis, ORL and TSM data are used. The meteorological summer systems of South America, as well as the phenomena associated with their variability, such as ENSO, 30-60 days oscillation and wavetrain pattern over the Pacific Ocean and South America are identified. Positive (negative) anomalies of precipitation in the south region of Northeast are related to the positive (negative) phase of ENSO. In the intraseazonal scale there is a connection between the variability of the SAZC, the SPZC and the upper cyclonic vortex of Northeast. It is pointed out that the wet pattern is related to the shift of the SAZC northward and the SPZC eastward and also with the tropical upper cyclonic vortex situated over the Atlantic Ocean. The dry pattern is associated with the SAZC displaced southwards and the tropical upper cyclonic vortex either close or over the continent. Atmospheric conditions both of the Amazon and North Atlantic have influence on the precipitation of the south region of Northeast. The rainy patterns are associated with intense convection over the east region of Amazon, shift of the $A B$ to the east, flow at low levels from the Amazon to the south region of Northeast and intensification of the northeast trade winds over the northern coast of South America. In the dry patterns the $A B$ is displaced to the west of its climatological position, that is from Amazon region to the south and weakness of the trade winds on the north coast of South America. Over the South Atlantic Ocean the rainy pattern is associated with the shift of Subtropical High eastward and weakness of the southeast trade winds over the Northeast coast. The dry pattern is related to strength and/or shift of the Subtropical High to west and intensification of the southeast trade winds. At high levels the weasterlies are more intense at subtropical latitudes over South America in the wet pattern than in the dry pattern . 


\section{OBSERVAÇÕES DO CONTEÚDO ELETRÔNICO TOTAL COM DADOS DO GPS \\ Fedrizzi, M.}

Dissertação de Mestrado em Geofísica Espacial, orientada pelo Dr. Ivan J. Kantor e pelo Dr. Eurico R.

De Paula, aprovada em 10 de março de 1999 (GES/INPE).

Um método para a obtenção do Conteúdo Eletrônico Total (CET), a partir das observáveis do "Global Positioning System" (GPS) é apresentado. A maior parte dos dados disponíveis de CET, no setor sul-americano, foi obtida através de medidas de rotação Faraday, que não contêm a contribuição dos elétrons situados acima de $2.000 \mathrm{~km}$ de altura. Todavia, valores de CET que incluem o conteúdo eletrônico plasmasférico, podem ser obtidos através dos dados de satélites GPS. O método utiliza-se da característica dispersiva do meio ionosférico para determinar o conteúdo eletrônico total a partir da diferença entre medidas de código e fase simultâneas, nas duas freqüências dos sinais enviados pelos satélites GPS. Medidas do CET foram obtidas através deste método para estações receptoras, pertencentes à rede "International GPS Service" (IGS), situadas nas regiões da América do Sul e Península Antártica. Os resultados permitiram efetuar um estudo da variação diurna, latitudinal e sazonal do CET, nestas regiões, para uma época de baixa atividade solar, em condições ionosféricas magneticamente calmas. Estes resultados são comparados com modelos empíricos de ionosfera (IRI-95) e plasmasfera (Gallagher-88). Uma análise dos dados em condições ionosféricas magneticamente calmas e perturbadas e a observação de flutuações ionosféricas, mostra o potencial do estudo do efeito das tempestades magnéticas e irregulariades ionosféricas a partir da utilização de dados do GPS.

\section{ONDAS ELETROSTÁTICAS GERADAS POR INTERAÇÃO DE FEIXE DE ELÉTRONS-PLASMA EM ALGUMAS REGIÕES DE PLASMA ESPACIAL: UM TRATAMENTO POR SIMULAÇÃO POR PARTÍCULAS}

Moraes, Márcio Augusto Ernesto de

Dissertação de Mestrado em Geofísica Espacial, orientado pela Dra. M. Virgínia Alves, aprovada em 11 de março de 1999 (GES/INPE)

Interações feixe de elétrons-plasma estão presentes em várias regiões de plasmas espaciais, como por exemplo, no vento solar, na região da frente de choque terrestre e na região auroral. Além disto, ondas de Langmuir excitadas por feixes estão relacionadas a emissões de rádio solar tipo III. O objetivo deste trabalho é investigar a evolução auto consistente da instabilidade feixe-plasma em algumas regiões do plasma espacial. Para tanto utilizamos a técnica de simulação por partículas usando o código computacional XPDP1, unidimensional, eletrostático, que permite condições de contorno não periódicas e a inclusão de um campo magnetostático externo. Os resultados são comparados com os obtidos via satélite, disponíveis na literatura.

\begin{abstract}
ELECTROSTATIC WAVES DRIVEN BY ELECTRON BEAM-PLASMA INTERACTION IN SOME REGIONS OF SPACE PLASMAS: A TREATMENT BY PARTICLE SIMULATION-Electron beam-plasma interactions are present in many regions of space plasmas, for example, in the solar wind, Earth's foreshock and auroral region. Besides, Langmuir waves driven by beams are related with the type III solar radio emission. The objective of this work is to investigate the self consistent evolution of the beam-plasma instability in some of these regions. For this, we use particle simulation technique by using the computational code $X P D P 1$, one-dimensional, electrostatic that allows non-periodic boundary conditions and static external magnetic fields. The results are compared with ones obtained via spacecraft, available in the literature.
\end{abstract}




\title{
ESTUDO DE NUVENS MAGNETIZADAS E GASES PROPULSORES NO MEIO INTERPLANETÁRIO
}

\author{
Dal Lago, Alisson
}

Dissertação de Mestrado em Geofísica Espacial orientada pelo Dr. Walter D. Gonzalez A. e pela Dra. Alícia L. C. De Gonzalez-A., aprovada em 10 de março de 1999

Nuvens magnéticas são estruturas interplanetárias originadas em ejeções de massa coronal solares - EMCS. São identificadas por possuírem: campo magnético intenso (normalmente > $10 \mathrm{nT}$ ); grande rotação do vetor direção do campo magnético enquanto a nuvem passa pelo ambiente espacial do satélite observador e medidor; baixa temperatura e baixo valor do parâmetro beta ((pressão térmica)/(pressão magnética) da ordem de 0,1). Esta dissertação apresenta um estudo das características e parâmetros de plasma e campo magnético das nuvens magnéticas, para um conjunto de eventos previamente publicados em literatura especializada e para um novo conjunto de eventos selecionado que ocorreram no ano de 1979. É apresentada a existência de uma correlação estatística linear entre a velocidade de propagação das nuvens magnéticas com o módulo da intensidade de seu campo magnético intrínseco, levando a conclusão de que: nuvens magnéticas que se propagam no meio interplanetário com maior velocidade possuem maior intensidade de campo magnético. Esta associação parece ser propriedade exclusiva de nuvens magnéticas, uma vez que outras ejeções de massa coronal interplanetárias - EMCI, não nuvens, não apresentam estas características e correlações. Os parâmetros velocidade e campo magnético estão relacionados à ocorrência de tempestades geomagnéticas. As interações entre nuvens magnéticas e estruturas circunvizinhas no meio interplanetário são aqui investigadas através do cálculo de pressão total: térmica, magnética e dinâmica, a fim de relacioná-las com a intensificação do campo magnético de nuvens magnéticas. Esta dissertação contribui para: a previsão do clima espacial através de medidas de velocidade, que podem ser feitas através de imagens de coronógrafos, dois a três dias antes de sua chegada a Terra; a investigação da ligação entre nuvens magnéticas e tempestades magnéticas terrestres; o estudo das interações entre nuvens magnéticas e estruturas do meio interplanetário.
STUDY OF MAGNETIC CLOUDS AND DRIVER GASES IN THE INTERPLANETARY MEDIUM-Magnetic clouds are interplanetary structures whose origins are related to Coronal Mass Ejections - CME. Their features are: strong magnetic field intensity (typically > 10nT); a large rotation in the magnetic field angle as the cloud crosses the spacecraft, low proton temperature and $\beta$ values $\sim 0.1$ ( $\beta=$ thermal pressure/magnetic pressure). For a set of previously published magnetic cloud events and another set of clouds identified in the whole year of 1979 we present a study of plasma and magnetic field parameters. We have shown the existence of a relationship between the peak magnetic field strength and peak velocity value of the cloud, with a tendency that clouds which move at higher speeds also possess higher core magnetic field strengths. There is also an indication that this relationship is peculiar to magnetic clouds, whereas other types of non-cloud driver gas, or Interplanetary Coronal Mass Ejection (ICME) events do not seam to show a similar relationship. Both parameters, velocity and magnetic field strength, are related to Magnetic Storms. It is also addressed the interaction between magnetic clouds and other features in the interplanetary medium by calculating the Total Static Pressure, Magnetic plus Thermal, and the Dynamic Pressure relative to other structures surrounding the cloud, investigating their possible relation to magnetic cloud field enhancement. This work contributes to: (1) Space Weather Forecasting, through the calculation of the magnetic cloud field strengths by knowing their velocities (the latter can be remotely measured by sequences of coronograph images); (2) the study of the relation between magnetic clouds and magnetic storms; and (3) the study of the interaction between magnetic clouds and other interplanetary structures surrounding it. 


\title{
CÁlCULO DE TRANSMISSÃO ATMOSFÉRICA PARA AVALIAÇÃO DE FUNÇÕES PESO DE SENSORES ORBITAIS EM MICROONDAS
}

\author{
José Ricardo Siqueira
}

Dissertação de Mestrado em Meteorologia,orientada pelo Dr. Eduardo Jorge de Brito Bastos e pelo Dr. Kioshi Hada ,aprovada em 11 de março de 1999

As funções peso de 10 canais da Advanced Microwave Sounding Unit(AMSU), calculadas utilizando o modelo de transferência radiativa Atmosphere Transmission at Millimetric na Submillimetric Wavelengths (ATM) foram com as do sistemas Advanced TIROS-N Operational Vertical Sounder (ATOVS). Dos dez canais, 5 referem-se às linhas de absorção do oxigênio em torno de $52,29 \mathrm{GHz}$, que constituem a unidade AMSU-A (canais 2,4,6 e 8) e os outros 5 estão associados às linhas de absorção do vapor d'água em torno de $183,3 \mathrm{GHz}$, que compõe a unidade AMSU-B (canais de 16 e 20). Foram utilizados perfis verticais atmosférico padrões do modelo ATM (tropical, latitudes médias de verão e inverno) e perfis verticais climatológicos de temperatura e umidade da atmosfera das regiões do Brasil. A atual versão do modelo ATM estabelece uma parametrização do coeficiente de absorção dos gases atmosféricos em microondas, mediante o fornecimento de perfis de pressão, temperatura, umidade e concentração de gases da atmosfera. Alguns parâmetros de entrada também são fixados, tais como: emissividade da superfície, ângulo de visada do satélite, freqüência central; do canal e outros. As funções peso calculadas utilizando os perfis atmosféricos do modelo são comparadas com as estabelecidas para o Brasil e com as da AMSU/ATOVS. Além disso, foi realizado um estudo sobre as variações espacial e sazonal das funções peso no Brasil. Também verificou-se a influência da emissividade da superfície terrestre e do ângulo de visada do satélite no cálculo das funções peso. Os resultados mostram uma consistência entre as funções peso para a maioria dos canais da AMSU-A. Para os canais da AMSUB, observou-se uma discrepância entre as funções peso obtidas com os diversos perfis climatológicos, sugerindose a definição de funções peso mais específica para o Brasil. A emissividade da superfície e o ângulo de visada do satélite exercem forte influência na definição de algumas funções das AMSU-A e AMSU-B.
CALCULATION OF ATMOSPHERIC TRANSMISSION FOR EVALUATION OF WEIGHT-FUNCTIONS OF ORBITAL SENSORS IN MICROWAVES-The weighting functions of the 10 Advanced Microwave Sounding Unit(AMSU) channels calculated from the Atmospheric Transmission at Millimetric and Submillimetric Wavelengths (ATM) model were to those of the Advanced TIROS-N Operational Vertical Sounder (ATOVS). Among the ten channels, five refer to the oxygen absorption lines around 55,29 GHz, that constitute the AMSU-A (channels 2, 4, 5, 6 and 8), while the other five are associated to water vapor absorption lines around $183,31 \mathrm{GHz}$, that compose the AMSU-B (channel 16, 17, 17, 18, 19 and 20). Standard atmospheric vertical profiles (tropical and midlatitudes in summer and winter) of the ATM model and the temperature and humidity climatological vertical profiles for five regions of Brazil were utilized. The actual version of the ATM model calculates the absorption coefficient of the atmospheric gases in microwave spectrum utilizing atmospheric vertical profiles of pressure, temperature, humidity and concentration of gases. Some input parameters are also included, such as: surface emissivity, view angle of the satellite, central frequency of the channel. The weighting functions calculated from the standard atmospheric vertical profiles of the model were compared to those for Brazil and the AMSU weighting functions. Moreover, space and seasonal variations of the weighting functions for Brazil were studied; the surface emissivity and the view angle of the satellite in the calculation of the weighting functions was verified. The results show consistency among the weighting functions for the majority of the AMSU-A channels. For the AMSU$B$ channels, a discrepancy among the weighting functions obtained with the climatological profiles was observed, suggesting a more specific definition of the weighting functions for Brazil. The surface emissivity and the view angle of the satellite exerted strong influence on some of the weighting functions of AMSU-A and AMSU-B channels. 


\title{
FENÔMENOS LUMINOSOS ESTRATOSFÉRICOS E MESOSFÉRICOS ASSO- CIADOS A NUVENS DE TEMPESTADES
}

\author{
Tavares, F. S. S. \\ Dissertação de Mestrado em Geofísica Espacial, orientada pelo Dr. Osmar Pinto Júnior e pelo Odim \\ Mendes Júnior, aprovada em 12 de março de 1999 (GES/INPE)
}

Este trabalho teve como objetivos principais: reunir conhecimentos sobre a natureza dos "sprites", que são emissões luminosas na média e alta atmosfera associadas a tempestades e relâmpagos descobertas apenas em 1989, criar uma metodologia própria para análise de relâmpagos e tempestades sobre as quais eles ocorrem e aplicar a metodologia desenvolvida num conjunto de sete dias nos quais "sprites" tivessem sido registrados. Foi estudado um conjunto de sete dias de intensa atividade de "sprites" no Meio Oeste dos Estados Unidos, registrados a partir de um sítio de observação localizado em Yucca Ridge, Colorado. A maioria dos "sprites" ocorreu em associação com relâmpagos positivos e a média do pico da intensidade da corrente desses relâmpagos era maior que a média do pico da intensidade do pico da intensidade de corrente do total de relâmpagos positivos das tempestades analisadas. Observou-se que relâmpagos positivos com picos de intensidade de corrente em torno de 40-50 kA produziram mais "sprites" que aqueles com outros valores. Um pequeno número de "sprites" parecia estar associado a relâmpagos negativos e a corrente total dos relâmpagos negativos se manteve alta durante o período de ocorrência de "sprites". A existência de um número significativo de "sprites" para os quais não foi possível encontrar relâmpagos positivos aos quais eles estivessem associados sugeriu a existência de um possível efeito cumulativo para os relâmpagos positivos, que faria parte dos mecanismos de geração de "sprites", ainda não bem compreendidos. Esse efeito não foi encontrado na análise das tempestades inteiras, portanto sugere-se que a possibilidade de ele existir apenas nas vizinhanças da região de ocorrência dos "sprites".

\section{STRATOSPHERIC AND MESOSPHERIC LUMINOUS} PHENOMENA ASSOCIATED TO THUNDERSTORMSThe main directions of this paper were: To gather together some knowledge about the nature of Sprites, that are emissions of light in the medium and high atmosphere associated with thunderstorms and cloud-to-ground lightning, only discovered in 1989, to develop a particular methodology in order to study the lightning of the Sprite associated storms, and to investigate a Sprite data set throughout the developed methodology. An ensemble of seven days with high activity of Sprites over Midwest USA, recorded from Yucca Ridge, Colorado, was studied. Most of the Sprites were associated with positive cloud-to-ground lightning and the average of the positive peak current of the Sprites associated lightning was higher than the same values for the storm's total lightning population. There were more Sprites associated with 40-50 kA positive lightning than with any other range of peak current. A small number of Sprites seemed to be associated with negative cloud-to-ground lightning and the total negative current stayed high during the Sprites' period. The existence of a significant number of Sprites without the parent positive lightning suggests the existence of a cumulative effect in the positive lightning population that would be part of the Sprites' generation mechanism, not very well understood yet. No cumulative effect was found in the analysis of the whole storm, suggesting that the cumulative effect would possibly only exist at the vicinity of the Sprites' generation region.

\section{DESENVOLVIMENTO DE UM SISTEMA DE CORREÇÃO DE FASE PARA O RADAR IONOSFÉRICO DE SÃO LUÍS DO MARANHÃO}

\author{
Denardini, C. M.
}

Dissertação de Mestrado em Geofísica Espacial, orientada pelo Dr. Mangalathayil A. Abdu e pelo Dr. José Humberto Sobral, aprovada em 12 de março de 1999 (GES/INPE)

Esta dissertação apresenta detalhes do desenvolvimento e construção da unidade de correção de fases, a qual foi implementada com sucesso, com ajuda dos engenheiros e técnicos da equipe e com a colaboração de outros grupos científicos. Ela é necessária para obter estabilização das fases e uma correta relação entre os sinais transmitidos por diferentes antenas. A unidade foi testada integrada ao radar de São Luís, quando sua operação foi conduzida durante a campanha operacional e observacional de agosto de 1998. Durante a campanha os primeiros dados da dinâmica das
DEVELOPMENT OF A PHASE CORRECTION SYSTEM TO THE IONOSPHERIC RADAR OF SÃO LUÍS DO MARANHÃO-This dissertation will present details of the development and construction of the phase correction unit, which was successfully implemented, with the help of the participating technical staff and collaboration with other scientific groups. It is needed for efficient functioning of the transmitting system and it is required to achieve phase stabilisation and correct phase relationship of the signals transmitted by the different antennas. The unit 
irregularidades foram registrados, com resolução temporal de 6 s e de altura de $2,6 \mathrm{~km}$. O software de análise utiliza a técnica da transformação de Fourier (FFT) para obter freqüência Doppler dos ecos das irregularidades, e portanto suas velocidades de deslocamento, em um grande número de faixas de alturas, as quais podem ser ajustadas para cobrir regiões de interesse específico, para estudos do eletrojato ou de bolhas de plasma. Ele também provê a potência integrada para cada altura, as quais possibilitam a geração do mapa de variação temporal de intensidade de potência (RTI) em função da hora local. A análise do dia 31 de agosto, o qual foi magneticamente perturbado, mostrou grande variação na intensidade do eletrojato equatorial. Descobriu-se que essas variações estavam relacionadas com flutuações no índice auroral (AE), nas intensificações no campo magnético do eletrojato equatorial (EEJ) e no índice Dst. Neste dia, a altura das irregularidades apresentou um mínimo próximo ao meio dia da hora local. Uma análise detalhada está em andamento. was tested with the radar at "São Luís" when its successful operation was conducted during an operational and observational campaign in August 1998. During this campaign the first data on the dynamics of electrojet irregularities were registered with a resolution of 6 s in time and $2.6 \mathrm{~km}$ in height. The data collected during a few days of the campaign are now being analysed. Preliminary results of analysis of some data are presented in this thesis. The analysis software utilises Fast Fourier (FFT) technique to extract the Doppler frequency of the electrojet irregularity echoes, and hence their velocities, at a large number of height bins, that can be adjusted to cover height regions of specific interest, for electrojet or plasma bubble investigations. It also provides the integrated spectral power at each height, which permits plots of RTI (Range Time Intensity) maps as a function of local time. Analysis done for 31 August, which was a magnetically disturbed day, shows large variation in electrojet intensity. Such variations are found to be associated with fluctuations in the Auroral Electrojet (AE), Equatorial Electrojet (EEJ) magnetic field intensities and in the Dst indices. Also the height of the electrojet irregularities on this day appears to show a minimum near local midday. Detailed analyses are under way.

\title{
ESTUDO SINÓTICO-DINÂMICO DE CICLOGÊNESE E USANDO VORTICIDADE POTENCIAL
}

\section{Beatriz Miky Funatsu}

\author{
Dissertação de Mestrado em Meteorologia, orientada pelo Dr. Manoel Alonso Gan e pelo Dr. Ernesto \\ dos Santos Caetano Neto, aprovada em 12 de março de 1999
}

Estudou-se um evento de ciclogênese que ocorreu sobre o Uruguai entre os dias 9 e 10 de julho de 1996, utilizando os dados diários de temperatura, pressão reduzida ao nível do mar, geopotencial, velocidade vertical e ventos, em 17 níveis isobáricos e isentrópica destes parâmetros meteorológicos e também na análise dos campos de vorticidade potencial. O ciclone extratropical estudado formou-se a partir da propagação de um vórtice ciclônico em altos níveis pré-existentes sobre o Pacífico, o qual se estendia até a superfície e ao cruzar a Cordilheira dos Andes, favoreceu a formação de um ciclone extratropical sobre a América do Sul. A análise sinótica do evento revelou que este caso pode ser "classificado" como ciclogênese orográfica, dada a importância fundamental que a presença da barreira montanhosa teve na intensificação da baroclínica em superfície que levou à formação do ciclone extratropical. Também a orografia levou à interação do vórtice em altos níveis com a onda estacionário induzida pela Cordilheira Andina, definindo uma estrutura baroclínica na vertical que alimentou um sistema em seu estágio de desenvolvimento (isto porque, se não houvesse montanha, o vórtice em altos níveis teria se propagado diretamente, sem alteração em sua magnitude ou trajetória).

\begin{abstract}
SYNOPTIC-DYNAMIC STUDY OF CYCLOGENESIS USING POTENTIAL VORTICITY-A case study of cyclogenesis that occured on 9-10 of July, 1996 over Uruguai was performed. The data utilized consists of the daily temperature, geopotential, pressure at mean sea level, vertical velocity and wind fields, at 17 isobaric levels, from NCEP. The study was based on isobaric and isentropic analysis of those meteorological parameters, and also on potential vorticity perspective. The extratropical cyclone formed from the propagation of a pre-existent cut-off low in the Pacific Ocean, which reached the surface, and crossed the Andes Cordillera. The synoptic analysis of this case revealed that this event can be "classified" as a lee cyclogenesis, since the existence of the mountain barrier was fundamental for the intensification of the surface baroclinicity, which, in turn, brought to the formation of the extropical cyclone. Also, the Andes Cordillera defined the vertical tilt of the system to the east, favoring the cyclonic vorticity advection at higher levels, above the warm thermal advection at low levels, and it defined the final baroclinic configuration that fed the system in its greater development stage. The numerical inversion of total and perturbation potential vorticity was also undertaken. The results revealed that evolution of the sys-
\end{abstract}


Invertendo numericamente os campos totais e da perturbação de vorticidade potencial, foi possível recuperar os campos de vento e geopotencial associados. Os resultados mostram que a circulação foi reproduzida pela parte dinamicamente balanceada do escoamento. tem can be recovered by the dynamically balanced part of the flow.

\section{ESTUDO OBSERVACIONAL DO BALANÇO DE ENERGIA EM ÁREAS DE FLORESTAS E PASTAGENS}

\section{José Alexandre da Costa Galvão}

\section{Dissertação de Mestrado em Meteorologia, orientada pelo Dr. Gilberto Fernando Fisch, aprovada em} 15 de março de 1999

Medidas micrometeorológicas de superfície realizadas nas áreas de florestas e de pastagem do Projeto ABRACOS na região Ji-Paraná foram utilizadas para analisar o comportamento do balanço de energia para o final da estação chuvosa e início da estação seca do ano de 1993 e avaliar a performance da radiação de onda de longa atmosférica estimada por fórmulas empíricas. De um modo geral, o início do período de estudo é caracterizado por um comportamento bastante variável da radiação solar incidente, com temperaturas máximas em torno de $31^{\circ} \mathrm{C}$ e um maior número de eventos de precipitações em ambos os sítios. Os valores diários mais elevados de umidade específica do ar foram observados nas florestas (acima de $20 \mathrm{~g} \cdot \mathrm{kg}^{-1}$ ) e os menores na pastagem (até $14 \mathrm{~g} . \mathrm{kg}^{-1}$ ). Algumas variações abruptas dessas variáveis foram registradas com o advento de friagens sobre a região. No entanto, o final do período é caracterizado por valores aproximadamente constante de radiação solar incidente, maiores amplitudes térmicas, valores mais baixo da umidade específica do ar e um número reduzido de eventos de precipitações. Durante o período chuvoso, a devolução de energia para atmosfera é realizada predominantemente pelo fluxo de calor latente cuja fração do saldo de radiação $\left(\mathrm{LE} / \mathrm{R}_{\mathrm{n}}\right.$ ) utilizada foi 0,79 na floresta e 0,65 da pastagem. Uma pequena parte $\left(H / R_{n}\right)$ é usada para o aquecimento da atmosfera, correspondendo a 0,17 na floresta e 0,20 na pastagem. No período seco, a floresta continua a utilizar uma maior quantidade de energia para evaporar e uma menor quantidade para aquecer o ar, enquanto que na pastagem a transferência de energia para a atmosfera ocorre em magnitude muito próximas dos fluxos de calor latente e calor sensível, principalmente nos horários entre 11 e 14 Hora Local (HL). No caso do evento de friagem, a devolução de energia para a atmosfera é realizada predominantemente pelo fluxo de calor latente antes da passagem, cuja fração do saldo de radiação $\left(\mathrm{LE} / \mathrm{R}_{\mathrm{n}}\right)$ foi de 0,79 para a floresta e 0,71 para a pastagem. Durante a friagem, a fração de $L E / R_{n}$ na floresta é maior que 1 , enquanto que na pastagem a fração de $L E / R_{n}$ de 0,88 . Após a passagem da friagem, a fração de $L E / R_{n}$ e $H R_{n}$ na floresta e na pastagem retornam ao padrão antecedente à friagem. No caso do vento nevoeiro, a forma de devolução de energia para a atmosfera também é realiza-
Micrometeorological observations of the Anglo-Brazilian Climate Study (ABRACOS) have been used to study the surface energy behavior of paired balance forest and pasture sites at Ji-Parana (RO) during the end of the wet season and the start of the dry season of 1993, and to test the validity methods used for estimating of the long-wave atmospheric radiation flux. In general, the beginning of the study period is characterized by a highly variable behavior of the total incoming solar radiation, with maximum temperature of $31^{\circ} \mathrm{C}$ and a greater number of precipitation events at both sites. The maximum values of specific humidity were observed at the forest (greater than $20 \mathrm{~g}^{\mathrm{kg}} \mathrm{g}^{-1}$ ) and minimum, at the pasture area (up $14 \mathrm{~g}_{\mathrm{kg}} \mathrm{kg}^{-1}$ ). Some large variations of these micrometeorological measurements were recorded during the "friagens" events. However, the end of period is characterized by a less variable total incoming solar radiation, greater thermal amplitudes, smaller values of specific humidity and a smaller number of precipitation events. During the wet period, the transfer of energy to atmosphere is done mainly by the latent heat flux, which used 0.79 of the net radiation $\left(L E / R_{n}\right)$ at forest site and 0.65 at the pasture site. The corresponding values to heat the atmosphere $\left(H / R_{n}\right)$ were 0,17 at the forest sites and 0.20 at the pasture site. In the dry period, the forest continues to use most of the energy to evaporation and less energy to heat to the air. At the pasture the transfer of energy to atmosphere is made likely by latent heat flux and sensible heat flux, mainly between 11 e 14 Local Hour (LH). During a "friagem" event, the transfer of energy to atmosphere is done mainly by latent heat flux (before the friagem crosses the region), which used 0.79 of the net radiation $\left(L E / R_{n}\right)$ at the forest and 0.71 at the pasture site. When the "friagem" is crossing the sites, the ratio $\left(L E / R_{n}\right)$ is greater than than 1 at the forest site and 0.88 at pasture site. After the "friagem" has crossed the area, the values of the ratio $L E / R_{n}$ and $H / R_{n}$ at forestand pasture sites return characteristic pre-friagem values. In the case offog, the transfer of energy to atmosphere is also done mainly by latent heat flux, and values of Bowen ratio were positives until $9 \mathrm{LH}$. The performance of 5 methods for estimating the long-wave atmospheric radiation flux $\left(L_{d}\right)$ were tested for a pasture site in Amazon. However, 
da predominantemente pelo fluxo de calor latente, cujos valores da razão de Bowen foram positivos até $9 \mathrm{HL}$. A performance de 5 diferentes modelos estimativas de radiação de onda longa da atmosfera $\left(\mathrm{L}_{\mathrm{d}}\right)$ foram avaliados para área de pastagem na Amazônia. De um modo geral, as estimativas de $\mathrm{L}_{\mathrm{d}}$ a partir desses modelos subestimam a $\mathrm{L}_{\mathrm{d}}$ medida, resultando em valores de desvio médio quadrático (DMQ) de 50,7 a 75,2 W.m-2 assim como valores negativos de erro médio absoluto (EMA) de -73,0 a $49,1 \mathrm{~W} \cdot \mathrm{m}^{-2}$. Isto pode estar relacionado aos coeficientes utilizados nessas equações que são específicas para os locais nos quais foram desenvolvidas, diferentes das condições ambientes de pastagem na Amazônia. Um ajuste local desses coeficientes foi realizado, obtendo-se, com isso, melhores estimativas, de $\mathrm{L}_{\mathrm{d}}$ pelos modelos em que a emissividade é função somente da temperatura do ar. Os índices das equações ajustadas, mostram coeficientes de correlações $\left(\mathrm{R}^{2}\right)$ próximos da unidade, pequenos valores (EMP)e (EMA) próximos de zero. the estimates of $H_{d}$ from these underestimates the $L_{d}$ values, when compared to the measurements. The root mean square ranges from 50.7 to $72.5 \mathrm{~W} . \mathrm{m}^{-2}$. The values of the mean bias error are negative and range from-73.0 to $-49.1 \mathrm{W.m}$ 2. This can be associated to the coefficients used by empirical equations, since they are specific to the place in which they had been developed. A local adjustment of these coefficients were made. Thus, much better estimates of $L_{d}$ were obtained by methods in which the emissivity is only function of the temperature. The statistical test of the adjusted equation show correlation coefficients near to unit, smaller values of root mean square error and mean bias error near to zero.

\section{ESTUDO DA FRONTOGÊNESE EM UM CICLONE DO TIPO SHAPIRO- KEYSER}

\section{Cássio Nogueira de Campos}

Dissertação de Mestrado em Meteorologia, orientada pelo Dr. Valdir Innocentini e pelo Dr. Ernesto dos Santos Caetano Neto, aprovada em 25 de março de 1999

Foram analisadas as previsões de pressão na superfície do modelo numérico de área limitada da Agência Meteorológica do Japão para o período de maio de 1997 até agosto de 1998. A área considerada foi imediatamente a leste da Cordilheira dos Andes e latitudes menores que $45^{\circ} \mathrm{S}$. um caso de ciclone, cujos efeitos foram noticiados pela imprensa, foi selecionado. Foi utilizada uma classificação na qual os ciclones são modelo norueguês ou do tipo Shapiro Keyser O ciclone selecionado foi classificado como do segundo tipo.

O ciclone selecionado foi simulado em dois modelos numéricos de área limitada: o modelo Eta e o modelo da Agência Meteorológica do Japão. Os campos de 950 e 500 hPa das previsões foram utilizadas para o cálculo de forçantes frontogenéticas que permitem dizer se a variação na intensidade do gradiente horizontal de temperatura é decorrente dos movimentos geostróficos, ageostróficos horizontal ou do movimento vertical. Através dos campos das previsões e das forçantes foram verificadas as principais características do modelo conceitual semi-geostrófico e as etapas de desenvolvimento da frontogênese em um ciclone do tipo Shapiro-Keyser.
FRONTOGENESIS STUDY IN A SHAPIRO-KEYSER CYCLONE-Surface pressure forecasts for the period of May 1997 to August 1998 of Japanese Meteorological Agency Model were studied. The area covered in this study lies on the east side of Andes Cordillera and latitudes lower than $45^{\circ} \mathrm{S}$. A cyclone whose effects were reported by important brasilian newspapers was selected. A classification of cyclones in the norwegian model or in the Shapiro-Keyser model was used. The selected cyclone resembles the second idealized model.

The selected cyclone was simulated in two limited area numerical models: The Eta model and the Japanese Meteorological Agency Model. The 950 and 500 hPa fields of forecasts were used to calculate frontogenetical forcings which allow to study individual variation in magnitude of the horizontal potential temperature gradient due to the geostrophic, horizontal ageostrophic, and vertical motions. Using forecast and the frontogenetical forcing fields the main caracteristics of the semigeostrophic conceptual model and the stages of a frontal development in a Shapiro-Keyser cyclone were verified. 


\title{
ALGUNS ASPECTOS TEÓRICOS E EXPERIMENTAIS DA CAMADA LIMITE SUPERFICIAL ACIMA DO PANTANAL MATOGROSSENSE
}

\section{Edson Pereira Marques Filho}

\author{
Dissertação de Mestrado em Meteorologia, orientada pelo Dr. Leonardo Deane de Abreu Sá e pelo Dr. \\ Kolavennu Panduranga Vittal Murthy, aprovada em 07 de maio de 1999.
}

Neste estudo foram utilizados dados medidos em torre micrometeorológica, localizada no município de Miranda $\left(19^{\circ} 6^{\prime} \mathrm{S}\right.$ e $\left.57^{\circ} 0^{\prime} \mathrm{W}\right)$, Pantanal Matogrossense para caracterizar aspectos da estrutura da turbulência na Camada Limite Atmosférica em período de transição entre a estação úmida e a estação seca. A Transformada em Ondeletas foi utilizada na análise dos sinais turbulentos, o que possibilitou a filtragem passa-alto dos dados turbulentos e a obtenção de diagramas em tempo-escala que mostraram aspectos interessantes da variabilidade das contribuições por escala para os fluxos turbulentos. É possível que as características do Pantanal semi-inundado favoreçam o surgimento de circulações locais e consequentemente, de flutuações de baixa frequiência, o que dificulta a definição de uma falha espectral e a separação entre média e flutuação turbulenta. Os dados medidos com instrumentos de resposta lenta, provavelmente dentro da subcamada de transição, mostraram alguma discrepância com as relações estabelecidas pela Teoria da Similaridade de Monin e Obukhov, especialmente para as trocas de momentum sob condições instáveis. Os dados obtidos com instrumentos de resposta rápida, medidos acima da subcamada de transições, apresentaram bom acordo com as parametrizações dos momentos turbulentos de segunda ordem. As características complexas do terreno não eram totalmente isotrópicas e a altura do deslocamento do planozero, calculado pelo método de De-Bruin e Verhoef, variou segundo a direção do vento médio. As informações fornecidas pelos espectros turbulentos das componentes horizontais de velocidade, permitiram que se estimasse razoavelmente bem, através da metodologia proposta por Liu e Ohtaki, a altura da camada de mistura para condições instáveis.

\begin{abstract}
SOME THEORETICAL AND EXPERIMENTAL ASPECTS OF THE SURFACE LAYER ABOVE THE “PANTANAL MATOGROSSENSE"-In this study data from the micrometeorological tower located at Miranda city $\left(19^{\circ}\right.$ $6^{\prime} S 57^{\circ} 0^{\prime} \mathrm{W}$ ), in the Pantanal Matogrossense, was used in order to characterize aspects of the structure of turbulence in the atmospheric boundary layer, in the transition period between wet and dry seasons. The Wavelet Transform was used in the analysis of the turbulent signals, which allowed the high-pass filtering of the turbulent data and the obtained time-scale diagrams showed interesting aspects of the variability of covariance contribution to turbulent fluxes in different scales. It is possible that the semi-flooded Pantanal characteristics favor the presence of local circulations, and as a consequece, low-frequency flutuations, makes difficult to define accurately the spectral flaw and the separation between the average and turbulent flutuation. The data taken from the slow response instruments showed some discrepancy compared to the relations established by the Monin-Obukov Similarity Theory, specially concerning the momentum exchanges under unstable conditions, probably due to the transition sublayer. The data measured from fast response instruments, taken above the transition sublayer, presented good agreement compared to the parameterizations of turbulent momentum of second order. The complex characteristics of the terrain were not totally isotropic and the displacement height of the zero-plane, calculated by the De-Bruin and Verhoef method, changed according to the average wind direction. The infomation given by the turbulent spectra of the horizontal components of velocity allowed a good estimation of the mixed layer height for unstable conditions, utilizing the methodology proposed by Liu and Ohtaki.
\end{abstract}




\title{
A IMPORTÂNCIA DO “DIA QUIETO”NA ABSORÇÃO IONOSFÉRICA DA CAMADA D DA IONOSFERA E SUA APLICAÇÃO PARA OS DADOS DE RIÔMETROS DA ESTAÇÃO ANTÁRTICA COMANDANTE FERRAZ
}

\author{
Brum, Christiano G. M. \\ Dissertação de Mestrado em Geofísica Espacial, orientada pelo Dr. René A. Medrano-Balboa, \\ aprovada em 31 de maio de 1999 (GES/INPE)
}

O Dia Quieto (QD) é usado para o cálculo da Absorção Ionosférica do Ruído Cósmico na Camada D da ionosfera. Sua utilização é importante no estudo de eventos transientes na ionosfera (de poucas horas a alguns dias). Para este trabalho foram utilizados dados (1987 à 1997) de três Riômetros instalados na Estação Antártica Comandante Ferraz $\left(68^{\circ} \mathrm{S}, 58^{\circ} \mathrm{W}\right)$, estando estes conectados a antenas apontadas para três direções diferentes (vertical, sul e oeste magnético). Para o estudo da variação de amplitude dos QDs do período analisado, foram escolhidos três QDs do início do mesmo período (1989), um para cada antena, os quais foram submetidos a um alisamento polinomial. A partir do alisamento polinomial destas três curvas pré-selecionadas (dia padrão), efetuou-se o cálculo da Absorção Ionosférica Relativa ( $\left.\mathrm{A}_{\mathrm{I}}\right)$, que é em essência a comparação logarítmica do dia padrão e o dia considerado calmo. Por fim criou-se o parâmetro da Absorção Ionosférica Relativa Total $\left(\mathrm{A}_{\mathrm{T}}\right)$, que é a integração da $\mathrm{A}_{\mathrm{I}}$ durante um dia. Este parâmetro $\left(\mathrm{A}_{\mathrm{T}}\right)$ quantifica a diferença da amplitude entre os dias quietos. Através da variação do $\mathrm{A}_{\mathrm{T}}$ durante o período estudado, constatou-se que o mesmo apresentou um comportamento oposto ao número de manchas solares (atividade solar) e semelhante a incidência de Raios Cósmicos Galácticos, registrados por monitor de neutrons em Thule e Climax (rigidez de corte magnética 0.00 e 2.97 , respectivamente). Tal fato sugere que houve uma contribuição acima do esperado dos raios cósmicos galácticos na ionização da Camada D da ionosfera. Esta interpretação é substanciada pelos altos valores dos índices de correlação linear obtidos entre os ajustes polinomiais de $\mathrm{A}_{\mathrm{T}}$ e dos ajustes polinomiais do número de partículas cósmicas incidentes $(\approx 0.970)$. Pelo deslocamento dos mínimos correspondentes aos ajustes polinomiais dos raios cósmicos e dos $\mathrm{A}_{\mathrm{T}}$ da antena vertical, comparados com o máximo do número de manchas solares, inferiu-se a ordem cronológica entre os fenômenos estudados. Estes resultados são consistentes com a ação da atividade solar que através do campo magnético interplanetário, modula a chegada dos raios cósmicos galácticos na atmosfera terrestre, modulando por sua vez, o estado de ionização da Camada D. Concluí-se também que não é possível determinar um QD padrão para um período extenso, uma vez os QDs dependem da atividade solar.
THE IMPORTANCE OF "QUIET DAY” IN THE IONOSPHERE ABSORPTION IN THE D-LAYER AND ITS APPLICATION TO THE DATA OF RIOMETERS OF ANTARTIC STATION COMANDANTE FERRAZ - The Quiet Day (QD) in riometer studies is used to compute the cosmic noise ionosphere absorption in the D-layer. Its use is specially important in the study of ionosphere transient events. In this work riometer data from three different directions (vertical, magnetic south and west) corresponding to the interval from 1987 to 1997 were used. The riometerantenna systems are installed at the Brazilian Antarctic Station Comandante Ferraz $\left(68^{\circ} \mathrm{S}, 58^{\circ} \mathrm{W}\right)$. Three $Q D$ s from the beginning of 1989 for each direction, were chosen as basis to study the amplitude variations of the QDs along the interval. A logarithmic comparison (here called "relative ionospheric absorption) of each of these pre-selected QDs with the quiet days along the interval was performed. In order to have a parameter that quantifies the amplitude variation a Total Relative Absorption $A_{T}$ index is introduced. The plot of $A_{T}$ shows an anti-correlation behavior with the sunspot number (which represents the solar activity) but it also shows a good correlation with neutron monitor data of the same period from Thule and Climax Stations (0 and 2.97 magnetic rigidity, respectively). These results suggest that the contribution of the galactic cosmic rays to the ionization of the D-region is more than expected. The correlation coefficients between the polynomial best fit of $A_{T}$ and the corresponding to the cosmic radiation are rather high $(\approx 0.970)$. From the lag time for the best fit of the cross-correlation was possible to infer a chronological order of the phenomena involved. The results obtained are consistent with what one would expect in terms of effect of the solar activity, through the interplanetary magnetic field, on the arrival of the galactic cosmic rays and, hence, on the ionization state of the D-region. It is also concluded that there is no single $Q D$ to be used for an extended period of time because of $Q D$ dependence on solar activity. 


\title{
EFEITOS DAS TEMPESTADES MAGNÉTICAS NA IONOSFERA DE BAIXA LATITUDE
}

\author{
Yamashita, Cristina S.
}

\author{
Dissertação de Mestrado em Geofísica Espacial, orientada pelo Dr. José H.A. Sobral e pelo \\ Mangalathayil A. Abdu, aprovada em 12 de agosto de 1999 (GES/INPE)
}

O objetivo desta dissertação é estudar os efeitos de tempestades magnéticas sobre a região $\mathrm{F}$ da ionosfera equatorial (Fortaleza) e de baixa latitude (Cachoeira Paulista) no Brasil. Esse tema de pesquisa é relativamente novo e bastante interessante para a comunidade científica internacional. Ele é, entretanto, complexo, pois envolve o conhecimento de estudos teóricos e experimentais sobre o comportamento do sistema ionosfera/termosfera/magnetosfera. Durante a ocorrência das tempestades magnéticas, as quais são basicamente caracterizadas como uma grande excursão negativa na magnitude do índice Dst, a ionosfera sofre perturbações substanciais em nível global. Os principais efeitos ionosféricos a serem investigados são os seguintes: 1) penetração de campos elétricos zonais (direção leste-oeste) desde a região auroral até a região equatorial e de baixa latitude; 2) efeitos de ventos termosféricos perturbados (Disturbance Dynamo). A metodologia a ser empregada para o estudo dos efeitos ionosféricos das tempestades magnéticas consiste basicamente na comparação dos parâmetros ionosféricos dos dias perturbados com os dias quietos. Para o comportamento quieto nós usamos o valor médio de um conjunto de dias quietos no intervalo de 15 dias em torno do início da tempestade magnética. Nossos resultados mostram intensas derivas de altura ( $h$ ' $F$ e hpF2) na região F e variações da freqüência crítica (foF2) que são discutidos aqui à luz dos parâmetros magnéticos como o índice auroral AE, componente do campo magnético interplanetário $\mathrm{Bz}$ (obtido pelo satélite ISEE3) e o índice Dst.

\begin{abstract}
MAGNETIC STORM EFFECTS IN THE LOW LATITUDE IONOSPHERE-The objective of this dissertation is to study the magnetic storm effects on the ionosphere F region over the equatorial region (Fortaleza) and the lowlatitude region (Cachoeira Paulista), in Brazil. This research subject is relatively new and interesting to the international scientific community. It is a complex topic since it comprises an assortment of coupled variations of physical parameters of the ionosphere/thermosphere/magnetosphere system. During the magnetic storms which are defined as large negative excursions in the magnitude of the Dst index; the ionosphere undergoes substantial perturbations in a global level. The main ionospheric effects focused here are: 1) zonal electric field penetration (east-west direction) stemming from the auroral region into the low and equatorial latitude regions; 2) effects of disturbed thermospheric winds (Disturbance Dynamo). The methodology adopted here to study magnetic storm effects in the ionosphere consists basically on the comparison of quiet and disturbed ionospheric parameters. For the quiet behavior we have used the average values of several quiet days taken in a time interval of \pm 15 days around the beginning of the magnetic storm. Our results show intense $F$ region ( $h$ ' $F$ and $h p F 2$ ) drifts and critical frequency (foF2) variations that are here discussed in the light of the storm parameters such as the auroral index AE, the northsouth component of the interplanetary magnetic field Bz as obtained by the ISEE3 satellite) and the Dst index.
\end{abstract}

\section{A CAMADA IONOSFÉRICA $\mathrm{F}_{3}$}

\author{
Barbosa Neto, Paulo F.
}

Dissertação de Mestrado em Geofísica Espacial, orientada pela Dra. Inez Staciarini Batista, aprovada em 13 de agosto de 1999 (GES/INPE)

Ionogramas gravados nas vizinhanças de Fortaleza $\left(4^{\circ} \mathrm{S}, 38^{\circ}\right.$ W; $7{ }^{\circ} \mathrm{S}$ latitude magnética), mostraram a evidência direta de uma camada adicional ocorrendo, geralmente, na altura virtual de $650 \mathrm{~km}$ em regiões próximas ao equador magnético, e preferencialmente na faixa de hora que varia de 0930 UT (0630 LT) a 1730 UT (1430 LT). Esta camada foi denominada camada $\mathrm{F}_{3}$ e sua evidência indireta tem sido discutida em recentes trabalhos de modelagens. A combinação do campo magnético dirigido para o norte com o campo elétrico leste-oeste produz uma deriva vertical ascendente que origina uma fonte de plasma no topo da ionosfera durante a manhã. Essa fonte eleva o plasma e sob condições adequadas de
THE IONOSPHERIC F LAYER - Ionograms recorded at vicinity of Fortaleza $\left(4^{0} \mathrm{~S}, 38^{\circ} \mathrm{W} ; 7^{\circ} \mathrm{S}\right.$ magnetic latitude) showed the direct evidence of an additional layer occurring, in general, about virtual height of $650 \mathrm{~km}$, in regions close to the magnetic equator, in a time range from height 0930 UT (0630 LT) to 1730 UT (1430 LT). This layer was named $F_{3}$ layer and its indirect evidence has been studied at modeling works. The north-south magnetic field combined with east-west electric field generates a plasma fountain at topside ionosphere during morning hours. Under the adequate conditions of magnetic field and wind the plasma fountain forms the additional $F_{3}$ layer at latitudes close to 
campo magnético e vento forma a camada adicional $\mathrm{F}_{3} \mathrm{em}$ latitudes próximas ao equador. Durante alguns períodos a camada $\mathrm{F}_{3}$ pode possuir densidade de pico maior que a densidade da camada $\mathrm{F}_{2}$, o que possibilita detecção por ionossondas localizadas no solo. Neste estudo é apresentada uma análise dos ionogramas registrados em Fortaleza para estudar a ocorrência da camada $\mathrm{F}_{3}$. A base de dados de Fortaleza foi analisada para estabelecer a dependência com estações do ano, atividade solar e atividade magnética. Além disso, tendo em vista o deslocamento do equador magnético para o norte, na região brasileira, estes dados foram utilizados para tentar estabelecer o limite (em termos de latitude magnética) de ocorrência da camada $\mathrm{F}_{3}$. Observou-se que a camada ocorre principalmente nos solstícios de dezembro e junho, durante períodos de baixa atividade solar e magneticamente calmos. Durante os períodos de equinócio a ocorrência da camada é mais baixa, em Fortaleza, não mostrando uma dependência muito bem definida com atividade solar e magnética. A comparação das observações com resultados de modelos mostraram que o vento do modelo HWM não é apropriado para descrever a dinâmica da região equatorial brasileira durante período de inverno, baixa atividade solar. the magnetic equator. The $F_{3}$ layer peak density can be greater than $F_{2}$ layer density during some hours, making it possible its observation from ground-based ionosondes. In the present work we show an analysis of ionograms registered at Fortaleza to study $F_{3}$ layer occurrence. Fortaleza data were used to establish the variation of the $F_{3}$ layer occurrence with season, solar activity and magnetic activity. Furthermore, the data was used to try to establish the limit ( in terms of magnetic latitude) of $F_{3}$ layer occurrence. We observed that the $F_{3}$ layer occurs mainly during December and June solstices of low activity years, and during geomagnetically quiet periods. The occurrence of the layer during equinoxes, on the other hand, does not show a well defined dependence on geomagnetic and solar activity. The comparison of observations with model results showed that the HWM wind model is not appropriate to describe the Brazilian low latitude dynamics during winter, low solar activity conditions.

\title{
OBSERVAÇÃO DA RADIAÇÃO ULTRAVIOLETA SOLAR TIPO B EM BANDA LARGA
}

\section{Echer, Ezequiel}

\author{
Dissertação de Mestrado em Geofísica Espacial, orientada pelo Dr. Volker W. J. H. Kirchhoff, \\ aprovada em 03 de setembro de 1999 (GES/INPE)
}

O Instituto Nacional de Pesquisas Espaciais (INPE) opera uma rede de medidores de radiação ultravioleta solar tipo B (UV-B) na superfície terrestre desde o ínício da década de 1990, em várias localidades no Brasil, na Bolívia, no Chile e na Antártica. Os instrumentos são constituídos de medidores de banda larga (Biômetro) e de banda estreita (radiômetro UV de superfície, espectrofotômetro Brewer). Várias análises de dados de UV-B são apresentadas, com ênfase em uma metodologia derivada do método de Langley para obtenção de espessuras ópticas atmosféricas na região espectral do ultravioleta. A metodologia foi aplicada aos dados de radiação global do espectrofotômetro Brewer. Os resultados obtidos para a espessura óptica atmosférica total foram comparados com resultados derivados de medidas de radiação direta utilizando também o Brewer, e a concordância entre ambos os resultados foi boa. Com isto, a obtenção dos dados de radiação UV-B da rede do INPE poderá ser usada também sistematicamente, para o estudo de aerossóis. A metodologia desenvolvida foi também testada com os Biômetros, apesar destes não se enquadrarem nos requisitos do método de Langley. Os resultados obtidos com os instrumentos Biômetros, para a espessura óptica atmosférica total, foram concordantes com os obtidos pelo instrumento Brewer, em 310 e $320 \mathrm{~nm}$.
OBSERVATIONS OF BROADBAND SOLAR UV-B RADIATON- The National Institute for Space Research (INPE) operates a network of solar ultraviolet B (UV-B) radiation meters, at ground level, since the 1990's, at sites in Brazil, Bolivia, Chile and Antarctica. Ultraviolet meters are broadband meters (UV-Biometer), and narrowband meters (Ground-based Ultraviolet Radiometers, Brewer Ozone Spectrophotometers). Several analyses of $U V-B$ radiation are presented, with emphasis on a methodology derived from Langley's method to calculate the atmospheric total optical depth in the UV-B. This methodology was then applied to global radiation data measured by the Brewer spectrophotometer. The total optical depths obtained with global radiation were compared with total optical depths obtained with direct radiation data, also measured by the Brewer spectrophotometer, with good match. The methodology to calculate optical depths was then tested also for UV-Biometer data, although these do not follow the Langley requirements. The results obtained with $U V$ Biometer data for total optical depth were in good agreement with optical depths calculated from the Brewer data, at 310 and $320 \mathrm{~nm}$. 


\title{
DESENVOLVIMENTO DE UM MÉTODO AUTOMÁTICO DE COBERTURA DE NUVENS
}

\author{
Souza, Mariza P. \\ Dissertação de Mestrado em Geofísica Espacial, orientada pelo Dr. Ênio Bueno Pereira, aprovada \\ em 03 de setembro de 1999 (GES/INPE)
}

Este trabalho descreve o desenvolvimento de uma nova metodologia para estimar o índice de cobertura de nuvens. O método emprega uma base de dados obtida em superfície, através de uma câmara digital com sensor tipo CCD (Charge Coupled Device), na faixa de radiação do visível e aquisição de imagens em RGB (Red, Green and Blue). Para analisar as imagens coletadas foi desenvolvido um algoritmo cuja função é a de classificar os píxeis, com base em um processo de decisão preestabelecido empiricamente por observadores de campo, determinando assim, a fração de céu encoberto por nuvens. Para isso foi empregada a transformação do espaço de atributos RGB para IHS (Intensity, Hue and Saturation) utilizando a saturação (S) na separação dos píxeis que correspondem a céu e a nuvens. A metodologia foi testada com imagens coletadas na Estação Antártica Brasileira Comandante Ferraz. Os resultados obtidos com a aplicação do algoritmo desenvolvido sobre essas imagens mostram que a técnica usada é adequada para o trabalho proposto. A validação da metodologia foi realizada por comparação com os dados oriundos da inspeção visual do céu no local e das respectivas imagens obtidas. Foram testados 2 blocos com 25 imagens, representando cenas de céu claro e encoberto e um bloco com 29 imagens referentes a céu parcialmente encoberto. O percentual de acerto para os píxeis das imagens do grupo classificado visualmente como céu claro ficou entre $94 \%$ e $99 \%$, para o grupo de céu classificado como totalmente encoberto entre $99,96 \%$ e $100 \%$. O percentual de acerto para céu parcialmente encoberto apresenta uma grande dificuldade de validação pela própria característica subjetiva do processo de identificação visual, normalmente empregado nas estações meteorológicas. Portanto, a avaliação dos resultados da classificação automática realizada pelo método, foi obtida pela análise de "estudo de casos" (case studies) com base em diversos estados de cobertura do céu. Esses casos foram escolhidos de forma a representar: (1) padrões de cobertura de nuvens no céu bem definidos (contornos das nuvens bem definidos) e; (2) céu com padrões pouco definidos e grande quantidade de nebulosidade (bordas de nuvens pouco definidas e/ou estados de cobertura indefinidos). Para essas condições, o programa de reconhecimento também exibe resposta coerente com o processo subjetivo de classificação baseado na inspeção visual. Foram classificadas pelo método imagens coletadas para diferentes valores de ângulo zenital e de estados de cobertura de nuvens. $\mathrm{O}$ algoritmo de classificação dividiu os resultados em três casos distintos: (1) efetivamente nuvens (11\% a 82,93\%); (2) estado indefinido (10\% a $23,41 \%)$ e (3) céu claro $(13,82 \%$ a $85,32 \%)$. Todos os grupos foram testados com nível de confiança de $99,73 \%$.
DEVELOPMENT OF A NEW METHOD TO DETERMINE THE EFFECTIVE CLOUD-COVER INDEX-This work describes the development of a new methodology to field-estimate the sky cloud coverage percentage. This method employs as data base digital images collected by a $C C D$ (Charge Coupled Device) camera, in the visible range of the solar spectra as RGB (Red-Green - Blue) compositions. An algorithm was developed to classify each pixel according to a decision process. This process was derived from empirical methods used by the meteorologists to classify the sky according to its cloud cover status. The method transforms the image attributes from the RGB space to the IHS (Intensity - Hue - Saturation) space. This allows the identification of the pixel contamination by clouds by using the information of the saturation $(S)$ component of the IHS space. This methodology was tested at the Brazilian Antarctic Station, Ferraz (62 $05^{\circ}$ 'S 58 23',5W). The classification results obtained by applying this new methodology are adequate for the aim of this project, which is the automatic ground determination of the cloud fraction index. The validation of the methodology was made by comparing the results of the method with the field-observation of the sky, and with the RGB images. For the validation process we used two blocks of 25 images each, representing clear-sky, and overcast-sky and one block with 29 images representing images with intermediate sky conditions. The accuracy of the method for clear-sky was between $94 \%$ and $99 \%$. For overcast conditions, the accuracy was between $99.96 \%$ and $100 \%$. For intermediate conditions, this validation was somewhat more empirical and was applied to some "case studies". Several cloud sky conditions were selected in order to (1) represent well-defined clouds (sharp boundaries between cloud and clear-sky), and (2) represent sky conditions where the boundaries between clouds and sky were not well defined and/or with random nebulosity or thin clouds. For these two types of skies the classification algorithm yielded three distinct classes of results: (1) effectively clouds (11\% to $82.93 \%$ ); (2) undefined situation (10\% to $23.41 \%)$; and clear sky (13.82\% to $85.32 \%)$. All these groups were tested within the level of confidence of $99.97 \%$. 